\title{
PRODUTIVIDADE E VALOR NUTRITIVO DE GENÓTIPOS DE ALFAFA SOB PASTEJO
}

\section{LYSSA OTANI}

Dissertação apresentada à Escola Superior de Agricultura "Luiz de Queiroz", Universidade de São Paulo, para obtenção do título de Mestre em Agronomia, Área de Concentração: Ciência Animal e Pastagens.

PIRACICABA

Estado de São Paulo - Brasil

Junho - 2003 


\section{PRODUTIVIDADE E VALOR NUTRITIVO DE GENÓTIPOS DE ALFAFA SOB PASTEJO}

\section{LYSSA OTANI}

Zootecnista

Orientador: Prof. Dr. CARLOS GUILHERME SILVEIRA PEDREIRA

Dissertação apresentada à Escola Superior de Agricultura "Luiz de Queiroz", Universidade de São Paulo, para obtenção do título de Mestre em Agronomia, Área de Concentração: Ciência Animal e Pastagens.

PIRACICABA

Estado de São Paulo - Brasil

Junho - 2003 


\section{Dados Internacionais de Catalogação na Publicação (CIP) DIVISÃO DE BIBLIOTECA E DOCUMENTAÇÃO - ESALQ/USP}

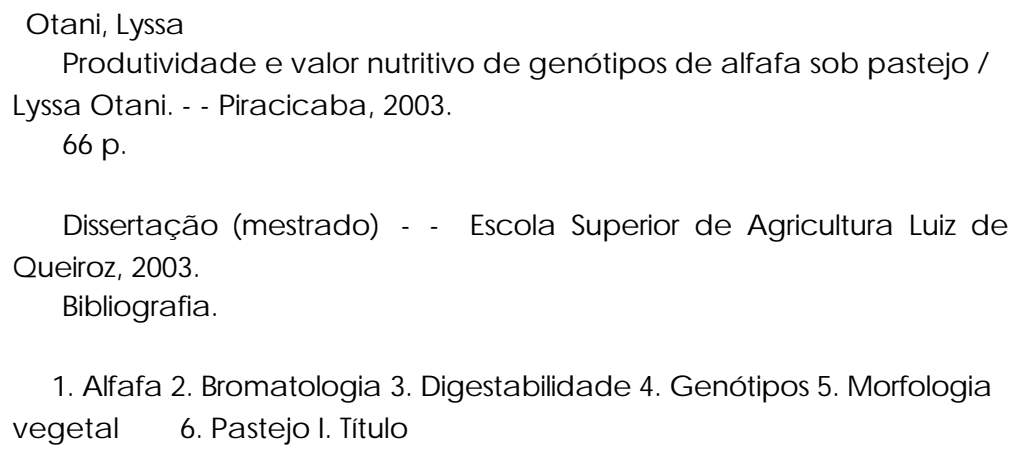

1. Alfafa 2. Bromatologia 3. Digestabilidade 4. Genótipos 5. Morfologia vegetal 6. Pastejo I. Título

CDD 636.08422 


\section{DEDICO}

A meus pais Satika Otani e Choyu Otani, minha irmã Lye Otani e meu irmão Yul Otani, pelo amor, apoio e incentivo

\section{OFEREÇO}

Aos meus amigos que fiz nesta etapa de minha vida pelos ótimos momentos que passamos e passaremos juntos. 


\section{AGRADECIMENTOS}

Ao Prof. Dr. Carlos Guilherme Silveira Pedreira pela excelente orientação, pelos ensinamentos e dedicação, e principalmente pela amizade desenvolvida.

À Fundação de Amparo à Pesquisa do Estado de São Paulo (FAPESP), pela concessão da bolsa de estudos de Mestrado.

Ao Coordenador Prof. Dr. Sila Carneiro Da Silva e a todos os professores do Curso de Ciência Animal e Pastagens, pela dedicação e conhecimentos transmitidos.

Ao Prof. Dr. Luiz Gustavo Nussio pela cordialidade e sugestões para a realização deste trabalho.

Ao Prof. Dr. Ricardo Andrade Reis pela valiosa ajuda na realização do trabalho.

Ao Dr. J. H. Bouton e ao Prof. Dr. Miguel Dall'Agnol pela troca de conhecimentos e sugestões para a realização do trabalho e fornecimento das sementes.

Ao Prof. Dr. Flávio A. P. Santos e ao Sr. Laureano pelo auxílio na concessão dos animais. Aos funcionários do Departamento de Zootecnia pela colaboração no preparo do solo.

Ao Prof. Dr. Valdo R. Herling, pela orientação na minha formação, amizade e constante incentivo.

Ao Prof. Dr. Cláudio Haddad pela predisposição e sugestões nas consultas técnicas. Ao Dr. Pedro Christofoletti e ao Sr. Luis Ferrari pelo fornecimento e aplicação de herbicida.

Ao Prof. Dr. César Gonçalves de Lima pelo auxílio na execução nas análises estatísticas. 
Ao técnico do Laboratório de Bromatologia da ESALQ-USP, Carlos César Alves e aos colegas Renato Schmidt e Fábio Campos, pelo auxílio na realização das análises bromatológicas.

Aos amigos Maria Del Carmen Ferragine, Felipe Tonato, Leonardo Moreno, João Menezes, Gustavo Braga, Henrique Rocha, Alexandre Mello, Daniel Rodrigues e estagiários do Departamento de Zootecnia, pela valiosa colaboração e disposição na realização de trabalhos a campo.

Às amigas Simone Gisele de Oliveria, Tathyana Batista de Abreu Chaves, Liana Calegare e Marta Velascos, com quem dividi minha moradia, alegrias e desabafos durante o tempo em que residi nesta cidade.

A todos os colegas do Curso de Ciência Animal e Pastagens, pela convivência alegre e constante troca de experiência e conhecimento.

Em especial a minha família pelo amor, carinho, apoio, incentivo e compreensão fundamentais durante estes anos transcorridos. 


\section{SUMÁRIO}

Página

LISTA DE TABELAS................................................................................. vii

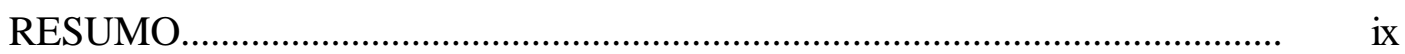

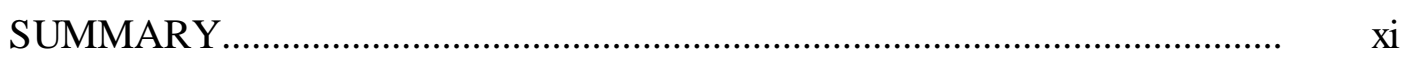

1 INTRODUÇÃO .................................................................................. 1

2 REVISÃO DE LITERATURA.............................................................. 3

2.1 A importância das pastagens para a pecuária................................................. 3

2.2 Origem e potencial forrageiro da alfafa...................................................... 5

2.3 Características qualitativas da forragem de alfafa..........................................

2.4 Fatores que influenciam as características qualitativas da alfafa.................... 12

3 MATERIAL E MÉTODOS....................................................................... 16

4 RESULTADOS E DISCUSSÃO............................................................. 23

4.1 Produtividade e distribuição estacional da produção de forragem................... 23

4.2 Composição morfológica de genótipos de alfafa sob pastejo........................... 29

4.3 Valor nutritivo de genótipos de alfafa sob pastejo........................................ 31

4.3.1 Digestibilidade in vitro da matéria seca de alfafa sob pastejo..................... 31

4.3.2 Teores de proteína bruta................................................................................ $\quad 35$

4.3.3 Teores de FDN, FDA e lignina.................................................................... 41

5 CONCLUSÕES................................................................................... 48

REFERÊNCIAS BIBLIOGRÁFICAS........................................................ 49 


\section{LISTA DE TABELAS}

Página

1 Resultado da análise química do solo da área experimental.

2 Precipitação total e temperaturas médias mensais do ar (máxima, mínima e média) durante o período experimental..

3 Combinações dos fatores considerados para a escolha dos genótipos

4 Acúmulo de forragem total de genótipos de alfafa sob pastejo, ao longo do período experimental.

5 Acúmulo de forragem de verão (AFV) e acúmulo de forragem de inverno (AFI) em genótipos de alfafa sob pastejo

6 Proporção dos acúmulos de forragem de verão (AFV) e de inverno (AFI) em alfafa sob pastejo em relação ao acúmulo de forragem total (AF) do período

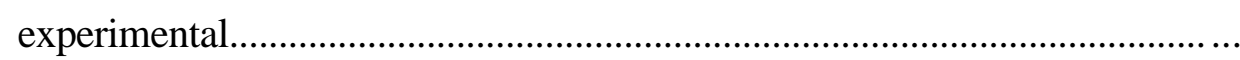

7 Taxa média diária de acúmulo de forragem no verão (TMDAV) e taxa média diária de acúmulo de inverno (TMDAI).

8 Porcentagem de folha em forragem de alfafa em resposta ao método de pastejo e à estação.

9 Porcentagem de haste em forragem de alfafa em resposta ao método de pastejo e à estação.

10 Valores de digestibilidade in vitro da matéria seca (DIVMS) da folha de alfafa sob lotação contínua no verão e no inverno. 
11 Valores de DIVMS da haste nos métodos de pastejo dentro das estações de verão e inverno.

12 Teor de proteína bruta (PB) na planta inteira nos métodos de pastejo e das estações.

13 Valores de $P$ para efeito da estação em cada combinação genótipo $\times$ método e de método na combinação genótipo $\times$ estação, para teor de PB nas folhas.

14 Teor de proteína bruta $(\mathrm{PB})$ da folha de alfafa sob pastejo no verão e no inverno

15 Teor de proteína bruta $(\mathrm{PB})$ da haste de alfafa sob pastejo no verão e no inverno

16 Teor de FDN na planta inteira nos métodos de pastejo no verão e no inverno.

17 Teor de FDN na haste de alfafa nos métodos de pastejo no verão e no inverno

18 Teor de FDA na folha de alfafa em resposta ao método de pastejo

19 Teor de FDA na folha de alfafa sob pastejo no verão e no inverno.

20 Teor de FDA na haste de alfafa sob pastejo no verão e no inverno

21 Teor de lignina na folha de alfafa sob pastejo no verão e no inverno 


\section{PRODUTIVIDADE E VALOR NUTRITIVO DE GENÓTIPOS DE ALFAFA SOB PASTEJO}

Autora: LYSSA OTANI

Orientador: Prof. Dr. CARLOS GUILHERME SILVEIRA PEDREIRA

\section{RESUMO}

A necessidade da redução do custo de produção animal nas propriedades rurais está se tornando crucial para a sobrevivência destes no mercado. Para a geração de alternativas viáveis de redução de custo é necessária a intensificação das pesquisas nos pontos de estrangulamento dos sistemas de produção animal baseados em pastagens. $\mathrm{O}$ uso de espécies de alto potencial forrageiro como a alfafa (Medicago sativa L.), pode ser uma opção para melhorar a produtividade de forragem e o desempenho animal, pois estes são capazes de associar elevada produção ao alto valor nutritivo. De março de 2001 a fevereiro de 2002, foi estudado o efeito do método de pastejo sobre a produtividade e o valor nutritivo de cinco genótipos de alfafa com aptidões contrastantes. $\mathrm{O}$ experimento do tipo "mob-grazing" foi realizado em área do Departamento de Zootecnia da ESALQ/USP, em Piracicaba, SP. O delineamento experimental foi o de blocos completos casualizados, com parcelas subdivididas (split-plot), com 10 tratamentos e seis repetições. Nas parcelas foi alocado o fator de tratamento relativo ao método de pastejo ("lotação contínua", simulada por desfolhas semanais, e "lotação rotacionada" com desfolha a cada 4 semanas na primavera-verão e a cada 6 semanas no outono-inverno). Nas sub-parcelas foram alocados 
os cinco genótipos de alfafa com diferentes aptidões agronômicas em termos de dormência, procedência e tolerância ao pastejo (ABT-805, Alfagraze, Crioula, CUF-101 e Pioneer 5432), submetidos a 295 dias de pastejo e sob irrigação. ABT-805 foi o genótipo mais produtivo sob lotação contínua (26,6 $\mathrm{Mg} \mathrm{MS} \mathrm{ha}^{-1}$ ) e no pastejo rotacionado (18 Mg MS $\left.\mathrm{ha}^{-1}\right)$. Alfagraze, apesar de ser um dos menos produtivos no pastejo rotacionado $(13,3 \mathrm{Mg}$ MS $h^{-1}$ ) apresentou semelhante produtividade ao ABT-805 no pastejo sob lotação contínua (26,3 Mg MS ha ${ }^{-1} \mathrm{ano}^{-1}$ ). Pioneer 5432 situou-se numa condição intermediária, com uma produção total de forragem de 24,3 e 15,3 $\mathrm{Mg} \mathrm{MS} \mathrm{ha}^{-1}$ sob lotação contínua e rotacionada, respectivamente. $\mathrm{O}$ valor nutritivo da planta inteira mostrou variação em função ao método de pastejo, enquanto que entre os genótipos que não se verificou diferença. O método de lotação contínua apresentou valores superiores de proteína bruta (PB) e digestibilidade in vitro da matéria seca (DIVMS) (349 e $810 \mathrm{~g} \mathrm{~kg}^{-1}$, respectivamente) em comparação a lotação rotacionada (238,5 e 757,8 $\mathrm{g} \mathrm{kg}^{-1}$, respectivamente). Os teores de fibra apresentaram comportamento inverso, sendo que a lotação continua foi inferior $\left(240 \mathrm{~g} \mathrm{~kg}^{-1}\right.$ fibra em detergente neutro, FDN, $182 \mathrm{~g} \mathrm{~kg}^{-1}$ fibra em detergente ácido, FDA e 34,9 $\mathrm{g} \mathrm{kg}^{-1}$ lignina) à lotação rotacionada (325 $\mathrm{g} \mathrm{kg}^{-1} \mathrm{FDN}, 255 \mathrm{~g} \mathrm{~kg}^{-1}$ FDA e 50,6 $\mathrm{g} \mathrm{kg}^{-1}$ lignina). A haste apresentou o mesmo padrão na composição químico-bromatológica que a planta inteira, onde o método de lotação contínua apresentou respostas superiores às da lotação rotacionada. A folha foi a fração que apresentou maiores variações nos teores de PB, FDA e lignina além da DIVMS em função dos parâmetros experimentais estudados (método de pastejo, estação e genótipo). ABT-805 e Alfagraze são os que apresentaram maiores produtividades com adaptação moderada ao pastejo nas latitudes tropicais do Brasil Central, mas para o seu sucesso deve-ser relevar as condições climáticas e do método do manejo do pastejo. 


\section{PRODUCTIVITY AND NUTRITIVE VALUE OF ALFALFA GENOTYPES UNDER GRAZING}

Author: LYSSA OTANI

Adviser: Prof. Dr. CARLOS GUILHERME SILVEIRA PEDREIRA

\section{SUMMARY}

The need for reduction in animal production costs on farms has become crucial to their survival in the market. In order to generate new alternatives research is needed on the factors that limit the success of pasture-based animal production systems. The adoption of species with high forage potential such as alfalfa (Medicago sativa L.), may be a viable option to improve forage productivity and animal performance, associating high production with high nutritive value. From March 2001 to February 2002 the effect of grazing method and genotype on forage productivity and nutritive value was studied. A mob-grazing experiment was carried out at ESALQ/USP in Piracicaba, SP. The experimental design was a randomized complete block with six field replications in a split-plot arrangement. The grazing method factor (continuous stocking, simulated by defoliation every seven days, and rotational stocking, simulated by defoliation every four weeks during the summer season and every six weeks during the winter season) was allocated at random to main plots which were grazed down to $7 \mathrm{~cm}$ at every grazing event. The alfalfa genotypes were allocated to the sub-plots, each of which representing a specific combination among agronomic characteristics regarding dormancy class, origin, and grazing tolerance (ABT-805, 
Alfagraze, Crioula, CUF-101, and Pioneer 5432). Plots were grazed over 295 days without water deficits, as sprinkler irrigation was provided as needed. ABT-805 was the most productive genotype under continuous (26,6 $\mathrm{Mg} \mathrm{DM} \mathrm{ha}^{-1}$ ) and rotational (18 $\mathrm{Mg} \mathrm{DM} \mathrm{ha}{ }^{-1}$ ) stocking. Although, Alfagraze showed the lowest production under rotational stocking (13,3 $\left.\mathrm{Mg} \mathrm{DM} \mathrm{ha}{ }^{-1}\right)$ it was the same as that of ABT-805, under continuous stocking (26,3 Mg DM ha ${ }^{-1}$ ). Pioneer 5432 showed intermediate productivity, with total accumulation of 24,3 (continuous) and $15,3 \mathrm{Mg} \mathrm{DM} \mathrm{ha}{ }^{-1}$ (rotational). The nutritive value of whole plant showed significant variation between grazing methods, although no difference among genotypes was found. Forage produced under continuous stocking had higher concentrations of crude protein $\left(\mathrm{CP} ; 349 \mathrm{~g} \mathrm{~kg}^{-1}\right)$ and in vitro digestible dry matter (IVDDM; $810 \mathrm{~g} \mathrm{~kg}^{-1}$ ) compared to rotational socking (238,5 and 757,8 $\mathrm{g} \mathrm{kg}^{-1}$, respectively). Fiber concentrations were the opposite of CP and IVDDM as they were lower for under continuous stocking (240 $\mathrm{g} \mathrm{kg}^{-1}$ neutral detergent fiber, NDF; $182 \mathrm{~g} \mathrm{~kg}^{-1}$ acid detergent fiber, ADF; and 34,9 $\mathrm{g} \mathrm{kg}^{-1}$ lignin) than under rotational stocking $\left(325,255\right.$, and 50,6 $\mathrm{g} \mathrm{kg}^{-1}$ for the same three fractions, respectively). Both the stem fraction and the whole plant samples had better chemical composition and digestibility under continuous than under rotational stocking. The leaf fraction was more variable in terms of nutritive value (CP, IVDDM, ADF, and lignin concentrations) and was affected by genotype, grazing method, and season. ABT-805 and Alfagraze appear to be the most promising genotypes for grazing systems in central Brazil because of their yield performance and nutritive value. Their success, however, will depend on climatic conditions and choice of grazing management. 


\section{INTRODUÇÃO}

A pastagem é um componente importante para a produção de carne, leite, lã, peles, entre outros produtos de origem animal, que são os mais expressivos componentes do PIB agrícola brasileiro. Atualmente, as pastagens comportam um rebanho de cerca de 167 bilhões de bovinos, distribuídos em todas as regiões do país, embora a tendência atual do rebanho seja de estabilização juntamente com a área das pastagens (Zimmer et al., 2002). O Brasil, por ter o maior rebanho comercial e por possuir áreas de pastagem em regiões de características distintas, permite a existência de vários sistemas de produção pecuária com diferentes graus de intensificação e de aplicação de tecnologia (Balsalobre et al., 2002).

O crescimento vegetativo da população brasileira juntamente com o aumento do poder aquisitivo que vem se consolidando nos últimos anos (IBGE, 2002) acarretam no aumento da demanda por alimento de origem animal (Balsalobre et al., 2002), aumentando, assim, a necessidade de aumento na eficiência produtiva. A adoção de novas tecnologias no setor agropecuário que reduzam os custos da produção animal tem sido fundamental para a sobrevivência da pecuária empresarial e devido a isso, a utilização de forragens de alta qualidade e produtividade em sistemas de pastejo intensivo tem sido considerada como uma importante alternativa (Belesky \& Fedders, 1997; Corsi et al., 1999).

A alfafa por apresentar uma grande plasticidade, tanto na sua utilização como na sua capacidade de adaptação a diferentes condições edafoclimátiacas, adquiriu importância mundial entre as forragens cultivadas ao longo do tempo, apresentando características agronômicas e qualitativas que proporcionam o seu uso tanto para pastejo 
como para formas conservadas. A sua capacidade de fixação biológica de nitrogênio é reconhecida como uma característica importante e desejável em sistemas de produção pecuária a pasto, devido ao impacto ambiental da adubação (Roston, 2001) junto com a dependência do petróleo, fonte não renovável, para a produção dos fertilizantes nitrogenados (Zimmer et al., 2002).

A escassez de informações sobre pastejo de alfafa no Brasil (Vilela, 1994; Oliveira et al., 2001) contrasta com o número significativo de trabalhos desenvolvidos em outros países. Devido à grande plasticidade da alfafa, ela tem se adaptado às mais diversas regiões do globo, e com isso a seleção dos melhores materiais ou do método de pastejo ideal segue critérios variados. O potencial de novos cultivares de alfafa com diferentes características quanto à capacidade produtiva e adaptação às condições edafoclimáticas do Brasil Central, quando submetidos a pastejo parece promissor e deve ser estudado. O objetivo desta pesquisa foi caracterizar o potencial produtivo e o valor nutritivo de genótipos de alfafa de aptidões contrastantes, em resposta ao método de pastejo, gerando informações inéditas sobre o potencial de uso dessa espécie forrageira sob pastejo em sistemas intensivos de produção animal no Brasil Central. Os objetivos específicos foram: avaliar a produção (medida como acúmulo de forragem total, de verão, de inverno e as respectivas taxas médias diárias de acúmulo de forragem); avaliar os parâmetros de valor nutritivo (composição químico-bromatológica e digestibilidade) em resposta ao método de pastejo durante o primeiro ano de produção, nas diferentes frações da planta (haste, folha e planta inteira). 


\section{REVISÃO DE LITERATURA}

\subsection{A importância das pastagens para a pecuária}

A agropecuária no Brasil tem grande importância no contexto sócio-econômico devido às condições edafoclimáticas que proporcionam uma ampla exploração de diferentes espécies animais e vegetais (Zimmer \& Euclides Filho, 1997). Estima-se que as áreas de pastagem ocupam cerca de $76 \%$ da superfície usada pela agricultura, o que corresponde a $20 \%$ da área total do país (Brasil, 1994) ou cerca de 180.000 .000 ha entre pastagens nativas e cultivadas (Zimmer et al., 2002).

A estabilização da economia a partir da década de 1990 tem incentivado o estabelecimento de mercados livres e competitivos, incluindo o setor agropecuário (Zimmer \& Euclides Filho, 1997). A adoção de novas tecnologias no setor agropecuário que reduzam os custos de produção tem sido fundamental, razão pela qual a utilização de forragens de alta qualidade e produtividade em sistemas de pastejo intensivo na pecuária deve ser considerada (Belesky \& Fedders, 1997; Corsi et al., 1999).

Atualmente, a preocupação com o meio ambiente tem sido amplamente discutida em várias partes do mundo. Os sistemas intensivos de produção animal estão contribuindo significativamente para o aumento da poluição e contaminação dos recursos hídricos. Além de ser um alimento de baixo custo e bem aproveitado pelos ruminantes, que transformam a planta em produtos desejáveis, como carne, leite e lã (Moore \& Nelson, 1995), o uso de forragem sob pastejo apresenta um baixo impacto ambiental (Roston, 2001). Nos EUA, a pecuária é uma das principais fontes de poluição dos recursos hídricos ultrapassando indústrias de refinarias, de produtos químicos e até 
frigoríficos. A Europa também tem tido problemas ambientais relacionados ao crescimento dos complexos agropecuários de carne, leite e aves principalmente em países densamente povoados (Roston, 2001).

Países como a Nova Zelândia, Argentina, Chile, Uruguai, algumas regiões da Austrália (Aguiar, 1999) e Estados Unidos (Parker et al., 1992), desenvolveram sistemas de produção animal de baixo custo utilizando a pastagem como alimento principal (Aguiar, 1999). A alimentação animal no sistema de produção, consiste em 50 a $60 \%$ dos custos totais (Kremer, 1999) e também é a principal responsável para o sucesso no desempenho reprodutivo, na saúde do rebanho e na produtividade (Santos \& Santos, 2001).

A adoção do pastejo em propriedades leiteiras nos Estados Unidos ainda é baixa devido à falta de informação sobre o seu potencial econômico. Apesar do pastejo ser o método de colheita de forragem mais econômico, é necessária a investigação de uma série de aspectos técnicos relativos a essa modalidade de colheita de forragem. A quantificação exata do impacto do pastejo sobre a produtividade e lucratividade da fazenda é um ponto de grande importância (Parker et al., 1992). O consumo restrito de nutrientes (quantidade e/ou qualidade) é um dos principais fatores limitantes da produção animal em pastejos (Euclides, 2000) e portanto, o levantamento de informações que descrevam a qualidade e a disponibilidade dos nutrientes em pastos intensamente pastejados é de grande importância (Parker et al., 1992).

A produção mundial de leite também vem sofrendo mudanças nos últimos anos devido a fatores como novos conceitos de globalização da economia, a criação do Mercosul, o aumento da competitividade entre os produtores e a busca pelo aumento da produtividade. $\mathrm{O}$ aumento da concorrência, em razão da abertura da economia para o mercado internacional, tem como consequência uma redução no preço do leite (Aguiar, 1999) sendo que uma das formas de se tornar competitivo é reduzir os custos de produção e aumentar a produtividade. Com o maior rebanho comercial e por possuir áreas de pastagem em regiões de características distintas, o Brasil possibilita a existência de sistemas de produção pecuária com diferentes graus de intensificação e de aplicação de tecnologia (Balsalobre et al., 2002). As áreas de pastagens, além de suportar os 
bovinos, comportam ainda cerca de 1,5 milhões de bubalinos, 9,6 milhões de equídeos, 18 milhões de ovinos e 10,6 milhões de caprinos (IBGE, 1993).

A produção brasileira de carne bovina no ano de 2001 foi de 6,8 milhões de toneladas, dos quais $800 \mathrm{mil}$ foram exportadas e o restante foi comercializado internamente, comparado com a produção de 1977 que foi de 2,4 milhões de toneladas (Balsalobre et al., 2002). Quanto à pecuária leiteira, considerando o aumento na utilização de novas tecnologias, aprimoramento genético dos animais, pacotes nutricionais mais sofisticados, justifica-se o aumento de $40 \%$ no volume ordenhado desde 1990 (Roston, 2001). Isso mostra que a pecuária é um dos principais componentes do PIB agrícola brasileiro, evidenciando a importância da incorporação de novas tecnologias para aumentar a eficiência de produção, uma vez que tanto a área de pastagem como o tamanho dos rebanhos parecem estar se estabilizando (Zimmer et al., 2002).

\subsection{Origem e potencial forrageiro da alfafa}

A alfafa é uma leguminosa forrageira perene, com hábito de crescimento ereto e folhas trifolioladas. Os folíolos têm forma variável podendo ser arredondada, ovalada ou lanceolada, são glabros, e com bordas superiores ligeiramente serrilhadas (Burkart, 1952). O sistema radicular é pivotante, com raiz principal profunda e coroa posicionada na região superficial do solo. É uma das poucas espécies cosmopolitas, sendo capaz de sobreviver desde temperaturas abaixo de $-25^{\circ} \mathrm{C}$ até acima de $50^{\circ} \mathrm{C}$ (Barnes \& Scheaffer, 1995). A utilização da alfafa na alimentação animal pode ser uma ferramenta de grande importância, principalmente em sistemas de produção tropicais onde geralmente se tem menor dependência na utilização de grãos ou concentrado aproveitando, assim, a contribuição dessa espécie forrageira na melhoria do valor nutritivo da dieta (Corsi et al., 1999). Nos EUA, a flexibilidade da utilização da alfafa pelos pecuaristas é maior que muitas outras leguminosas, podendo ser na forma de feno, silagem e forragem pastejada (Van Keuren \& Matches, 1988). 
A alfafa, nativa da Eurásia (Michaud et al., 1988; Small \& Jomphe, 1989), é atualmente cultivada no Brasil em torno de 30 mil hectares distribuídos entre Rio Grande do Sul (80\%), Santa Catarina, Paraná, São Paulo e Minas Gerais (Basigalup, 2000; Dall'Agnol \& Scheffer-Basso, 2000), sendo direcionada, preferencialmente, para a produção de feno (Corsi et al., 1999). O uso da alfafa tem sido incentivado, visando a produção de alimentos de elevado valor nutritivo para gado leiteiro e suínos, bem como pelo interesse sempre crescente pelas criações especializadas de equinos (Oliveira et al., 1993).

A alfafa é uma fonte econômica e produtiva de proteína (Barnes \& Sheaffer, 1995) para animais em pastejo devido à sua independência de nitrogênio do solo. Apesar disso ela necessita de solos profundos e bem drenados, sendo exigente quanto à fertilidade do solo (Lanyon \& Griffith, 1988). A proteína da alfafa possui um balanço adequado de aminoácidos principalmente para animais não-ruminates como suínos, aves e equinos. Além de ser uma ótima fonte de proteína, a alfafa é fonte de $\mathrm{Ca}, \mathrm{Mg}, \mathrm{P}$, próvitamina A (caroteno) e vitamina D (Van Keuren \& Matches, 1988), embora seja deficiente em energia principalmente para animais de alta produção (Marten et al., 1988).

Para que a alfafa seja utilizada com sucesso e seja uma cultura forrageira mais versátil, melhoristas de plantas vêm procurando aumentar a tolerância de espécies ao pastejo (Smith et al., 1992) sem que a sua qualidade e produtividade sejam prejudicadas (Bouton, 1999). A maioria dos cultivares resistentes ao pastejo foi desenvolvida a partir da subespécie falcata devido à sua característica de crescimento rasteiro (Smith et al., 1989) e essas plantas, quando pastejadas, podem apresentar aumento na cobertura do solo e com isso produzir tanto quanto os cultivares de hábito de crescimento ereto (Bittman \& McCartney, 1994). Os cultivares que contêm genes de Medicago falcata são geralmente caracterizados como dormentes, de crescimento prostado e bastante ramificado em dias curtos, podendo apresentar-se de forma ereta não-ramificada como a M. sativa em dias longos (Christian, 1977).

Em estudos envolvendo o pastejo de alfafa ficou estabelecida a necessidade do aprimoramento de técnicas para a seleção eficiente das plantas tolerantes ao pastejo. A 
seleção de novos germoplasmas de alfafa tolerantes ao pastejo tem sido feita através do pastejo severo e de lotação contínua, onde as plantas sobreviventes são multiplicadas e testadas novamente. Esse método tem provado ser eficiente para selecionar indivíduos tolerantes ao pastejo (Smith et al., 1989; Smith \& Bouton, 1993). A seleção de plantas sob pastejo severo aumenta a probabilidade desses materiais persistirem sob outros métodos de pastejo, a princípio menos severos, como o pastejo rotacionado (Bates et al., 1996; Brummer \& Moore, 2000). Em trabalhos de melhoramento e seleção, para que sejam evidenciadas as diferenças de tolerância ao pastejo entre os materiais em teste normalmente são necessárias duas estações de seleção de plantas tolerantes, principalmente em se tratando de países de clima temperado onde as estações de pastejo são geralmente curtas (<160 dias) (Smith \& Bouton, 1993).

Bittman \& McCartney (1994) argumentaram que a ausência de interação entre germoplasma e manejo de pastagem geralmente indica que a frequência de pastejo não afeta a classificação do germoplasma, embora o declínio do germoplasma nãopersistente seja logo visualizado assim que o pastejo é intensificado. Devido a isso, a avaliação de um grande número de diferentes germoplasmas pode ser feita através da técnica de mob-grazing, que consiste em colocar em uma determinada área um grande número de animais, tendo como consequência um pastejo rápido e uniforme.

No Brasil, o cultivar Crioula surgiu de seleção natural nos estados do Rio Grande do Sul e Santa Catarina pela Estação Experimental de Lages. O cultivar tem como características a "rápida recuperação após o corte, boa produtividade, boa distribuição estacional da produção, e grande persistência sob corte" (Nuernberg et al., 1990). A produtividade depois de dez anos de experimento na Estação Experimental de Lages foi de 7 a $10 \mathrm{Mg} \mathrm{ha}^{-1}$ ano $^{-1}$ sendo que de 1,5 a 2,0 $\mathrm{Mg} \mathrm{ha}^{-1}$ ano $^{-1}$ foram obtidas no inverno (Nuernberg et al., 1990).

A Estação Experimental de Agricultura da Geórgia (Georgia Agricultural Experiment Station), nos Estados Unidos, desenvolveu um cultivar que foi lançado em Fevereiro de 1990, denominado Alfagraze (Bouton et al., 1991). A Alfagraze foi desenvolvida para o duplo propósito por ser tolerante ao pastejo e altamente produtiva quando manejada para fenação (Smith et al., 1989; Bouton et al., 1991). Sob pastejo 
intenso demonstrou ser mais persistente que os outros cultivares testados, além de manter o valor nutritivo e proporcionar bom desempenho animal (Smith et al., 1989; Hoveland et al., 1990, citados por Bouton et al., 1991). A seleção das linhagens parentais usadas no cruzamento para obtenção do novo material foi feita com base na habilidade dessas linhagens de sobreviverem a superpastejo sob lotação contínua (Bouton et al., 1991). Com o desenvolvimento da Alfagraze foi demonstrado que a tolerância ao pastejo e o alto potencial produtivo podem ser obtidos no mesmo cultivar (Bouton, 1999; Kallenbach et al., 2002). Brummer \& Moore (2000) observaram que após quatro meses de pastejo sob lotação contínua os cultivares tolerantes, como a Alfagraze, possuíam mais de $80 \%$ de cobertura de solo enquanto os não tolerantes foram severamente reduzidos. Bates et al. (1996) avaliaram dois cultivares de alfafa, Alfagraze e o Apollo. Alfagraze proporcionou melhor desempenho animal $\left(0,96 \mathrm{~kg} \mathrm{dia}^{-1}\right)$ e por área $\left(529 \mathrm{~kg} \mathrm{ha}^{-1}\right)$. O cultivar Apollo, que possui características mais adequadas para a fenação, demonstrou resultados inferiores em relação a Alfagrze (desempenho de $0,8 \mathrm{~kg}$ cabeça $^{-1}$ dia $^{-1}$ e produtividade de $464 \mathrm{~kg} \mathrm{ha}^{-1}$ ano $^{-1}$ ).

O teor de carboidratos totais não-estruturais acumulados nas raízes pode ser um indicativo de persistência e tolerância ao pastejo (Smith et al., 1989) e a alfafa é conhecida pelo seu padrão cíclico de armazenamento e uso do carbono (Smith, 1960 citado por Smith, 1989). A habilidade de manter alto teor de carboidratos de reserva durante períodos longos de utilização aumenta a capacidade da alfafa de tolerar o pastejo, o que ocorre devido à alocação de fotoassimilados para a raiz ou pelo uso limitado dos carboidratos de reserva (Brummer \& Bouton, 1992). Genótipos tolerantes ao pastejo sob lotação contínua aparentam ser menos dependentes dos carboidratos de reserva para a rebrota que os genótipos não tolerantes (Counce et al., 1984).

A tolerância ao pastejo também pode estar relacionada com a área foliar residual e o vigor de rebrota. Plantas que apresentam hastes decumbentes com um acúmulo de tecido próximo ao nível do solo podem armazenar maiores quantidades de fotoassimilados. Para Alfagraze, altura de resíduo menor que $5 \mathrm{~cm}$ favorece a produção e reduz a infestação de plantas invasoras. O cultivar é menos capaz de manter populações de brotos quando se aumenta a altura do resíduo, juntamente com o declínio 
da densidade de coroas, mostrando adaptação a intensidades de desfolha maiores (Belesky \& Fedders, 1997). Sendo assim, os sistemas de produção que utilizam alfafa sob pastejo requerem manejo de desfolha cuidadoso para a manutenção dos estandes (Brummer \& Bouton, 1991; Smith et al., 1989).

O potencial da alfafa, em sistemas de produção animal baseados em pastagens, é evidenciado nas pesquisas realizadas avaliando o seu potencial em diferentes métodos de pastejo e para diferentes espécies animais. Karnezos et al. (1994), estudaram a produção de carneiros em diferentes pastagens no sudoeste dos Estados Unidos e concluíram que pastagens de alfafa Cimmaron e Onobrychis viciifolia (Scop.) cv. Renumex proporcionaram oportunidades para maior desempenho animal na primavera e também uma maior produção de carneiros por hectare. A alfafa, em um ano de experimento, proporcionou um ganho de peso médio de $14,15 \mathrm{~kg}_{\text {animal }}{ }^{-1}$, a produção de carneiros por hectare foi na média de $808 \mathrm{~kg} \mathrm{ha}^{-1}$, e o peso médio das carcaças foi de $24,5 \mathrm{~kg}$. As diferenças nas medidas de carcaça entre os tratamentos refletem o valor nutritivo e/ou a diferença morfológica da forragem consumida. O Brasil e Argentina têm realizado trabalhos com pastagens exclusivas de alfafa mostrando o potencial da produção leiteira, Vilela (1994) obteve uma produção ao redor de $25 \mathrm{~kg} \mathrm{leite}^{-1}$ vaca $^{-1}$ dia $^{-1}$ e Gallardo (1996) obteve a produção de $20 \mathrm{~kg}_{\text {leite }}{ }^{-1}$ vaca $^{-1}$ dia $^{-1}$.

\subsection{Características qualitativas da forragem de alfafa}

O valor nutritivo da forragem é, tradicionalmente, estimado através das concentrações de proteína bruta (PB) e parede celular (FDN, FDA e lignina) e através da digestibilidade tanto in vivo como in vitro (Paterson et al., 1994).

O aspecto qualitativo da forragem é um fator de grande importância em um sistema de produção animal no pasto, principalmente em se tratando de sistemas que utilizam alfafa como forragem (Hintz \& Albrecht, 1991). A qualidade da forragem, definida como o potencial desta em produzir leite, carne ou outros produtos de uso humano (Turnbull et al., 1982), está diretamente associada aos custos de alimentação (Hall et al., 2000). Para que a forragem seja bem utilizada como alimento em sistemas 
de produção que incluem o pastejo, o valor nutritivo é um fator importante, competindo com grãos e outros suplementos (Moore \& Nelson, 1995), principalmente em se tratando de animais leiteiros que precisam ingerir uma quantidade mínima de fibra insolúvel para o bom funcionamento do rúmen (Van Soest et al., 1991) e manter um teor normal de gordura no leite, entre 2,8 a 3,2 \% (Turnbull et al., 1982).

Estimar a concentração da parede celular na forragem é de grande importância devido à sua grande participação na matéria seca, que pode variar de 25 a $85 \%$ e por estar correlacionada com o consumo e a digestibilidade da forragem (Buxton \& Hornstein, 1986; Paterson et al., 1994). A parede celular é composta de polissacarídeos estruturais como a celulose e a hemicelulose (Paterson et al., 1994). O aumento na concentração de parede celular da forragem durante o desenvolvimento da haste é o resultado do espessamento da parede primária e secundária, onde a concentração de pectina decresce rapidamente enquanto que celulose, hemicelulose e lignina aumentam (Jung \& Engels, 2002), sendo que nas folhas o aumento na parede celular é quase inexistente (Nelson \& Moser, 1994). Quando a alfafa atinge o estágio de florescimento, a concentração de celulose tende a ser constante e os carboidratos estruturais, compostos principalmente de hemicelulose tende a diminuir (Albrecht et al., 1987; Jung \& Engels, 2002).

A parede celular é um dos principais responsáveis pela redução na degradabilidade dos tecidos das hastes de alfafa (Jung \& Engels, 2002). Isto é devido à deposição de lignina na parede celular de hastes que aumenta conforme a planta cresce (Albrecht et al., 1987) e segue uma concentração decrescente da base até topo da planta (Buxton \& Hornstein, 1986; Marten et al., 1988; Smith, 1970a). A degradação dos polissacarídeos (celulose, hemicelulose e pectina) da parede celular é mais intensa nas 12 primeiras horas em contato com os microrganismos ruminais (Jung \& Engels, 2002). A pectina é uma fonte de carboidrato solúvel altamente digestível, principalmente em leguminosas como a alfafa (Van Soest et al., 1991). A celulose e a hemicelulose, normalmente, apresentam um baixo potencial de degradação em comparação com a pectina, mesmo em tempo ilimitado de incubação (Buxton \& Brasche, 1991). Existe grande variação na degradação dos monômeros, sendo que os açúcares menos 
degradáveis são a xilose e a glicose. Esse padrão de degradação ocorre devido à grande concentração destes polissacarídeos em tecidos lignificados como os tecidos do xilema (Jung \& Engels, 2002).

A alfafa, também tem como característica, um elevado nível de compostos nitrogenados, que pode estar na forma de proteína ou de nitrogênio não-protéico (NNP). A fração NNP é caracterizada por conter oligopeptídeos, aminoácidos livres e compostos contendo amônia, normalmente, prevalecendo nas forragens com elevado valor nutritivo (Nussio \& Manzano, 1999). Segundo Broderick (1995) cerca de 66\% da proteína contida nas folhas das leguminosas está na forma de ribulose-1,5-bifosfato carboxilase (Rubisco), denominado de Fração 1 sendo que a Fração 2 é representada por outras proteínas enzimáticas. Os 30\% restantes são encontrados nas membranas das células, normalmente associadas com os ácidos nucléicos, com a fração de extensinas e com a estrutura de microfibrila da parede celular.

Normalmente, o perfil da fração nitrogenada é estudado na alfafa fenada ou ensilada, associado ao metabolismo ruminal do nitrogênio em gado de leite confinado (Hristov et al., 2001; Tremblay et al., 2000; Yang, 2002). Porém, a proteína solúvel na alfafa utilizada em sistemas de pastejo pode causar timpanismo (Dall'Agnol \& SchefferBasso, 2000). O timpanismo é uma desordem digestiva que se desenvolve em animais ruminantes onde há uma alta produção de gases na forma espuma onde a expulsão destes gases é dificultada, resultando no aumento do volume e na pressão intra-ruminal (McMahon et al., 2000). O timpanismo pode ocorre em animais pastejando alfafa no estádio vegetativo devido a altas concentrações de proteínas solúveis, tanto a Fração 1 (Rubisco) como a Fração 2, tornando sua degradação no rúmen mais rápida (Columan et al., 2000). A presença de saponinas na alfafa também era considerada como potencial causadora, porém Majak et al. (1980) não relataram a ocorrência de timpanismo em animais alimentados com alfafa com alto teor de saponina. Além do timpanismo existe outro fator antiqualitativo denominado fitoestrogêneo, que refere aos hormônios que afetam a reprodução de animais em pastejo causando infertilidade, apesar de que nos Estados Unidos este problema não está relacionado ao pastejo de alfafa (Dall'Agnol \& Scheffer-Basso, 2000; Van Keuren \& Matches, 1988). O timpanismo pode ser evitado 
através de algumas precauções que podem ser adotadas pelos produtores como utilizar preventivos, formar pastagens consorciadas, e pastejar a alfafa em estádios mais avançados (Dall'Agnol \& Scheffer-Basso, 2000).

Forragens em estádio de desenvolvimento avançado são mais resistentes à quebra mecânica e consequentemente à quebra microbiológica, o que resulta em menor taxa de passagem e aumenta o tempo de retenção do alimento no trato gastro-intestinal, diminuindo o consumo (Bailey et al., 1990; Lamb et al., 2002). O tempo de retenção ruminal proporciona a redução do tamanho de partícula aumentando a oportunidade para a digestão e quebra das partículas (Yang et al., 2002). Vinculado ao tempo de retenção ruminal tem-se a taxa de fermentação que estabelece a quantidade de energia gerada pelo alimento para as bactérias ruminais por unidade de tempo. Taxas de fermentação mais altas proporcionam maior consumo de forragem e com isso maior desempenho animal (Paterson et al., 1994). A taxa de digestão dilui o custo de manutenção para todas as bactérias ruminais e quanto mais rápida for a fermentação de carboidratos maior a eficiência ruminal (Van Soest et al., 1991). Portanto, para que a forragem seja considerada de alta qualidade, ela deve apresentar uma boa composição química, o que conseqüentemente levará a um alto consumo. $\mathrm{O}$ consumo além de ser influenciado pela taxa de digestão e pela taxa de passagem do alimento pelo rúmen (Shaver et al., 1988), é influenciado pelas características morfológicas da planta e pela estrutura do dossel da pastagem (Chermey et al., 1990; Hodgson, 1990).

\subsection{Fatores que influenciam as características qualitativas da alfafa}

A qualidade da alfafa é maior que de gramíneas perenes (Sleugh et al., 2000) com o mesmo estádio de desenvolvimento principalmente devido ao potencial de ingestão associado com a alta digestibilidade (Marten et al. 1988). O valor nutritivo da alfafa sofre variações devido à sua taxa de crescimento, o que por sua vez é influenciado por fatores edafo-climáticos, método de pastejo ou de corte, pela relação haste/folha (Sheaffer et al., 1998; Buscaglia et al., 1994), e por doenças e danos causados por insetos (Marten et al., 1988). 
Os fatores ambientais podem influenciar o crescimento tanto positivamente como negativamente. Estresses ambientais, como a baixa pluviosidade ou baixas temperaturas, podem diminuir a taxa de crescimento e o desenvolvimento da planta, mantendo, assim, o valor nutritivo da forragem por um período maior (Sleugh et al., 2000; Van Soest, 1982). A temperatura está fortemente associada com a maturidade da planta e portanto relacionada com a qualidade da forragem (Christian, 1977; Griffin et al., 1994; Kalu \& Fick, 1981, 1983; Smith, 1970a). A alfafa mostra-se produtiva e com altas taxas de crescimento em temperaturas máximas entre 21 e $27{ }^{\circ} \mathrm{C}$ e mínimas entre 15 e $21{ }^{\circ} \mathrm{C}$ mínima (Smith, 1970a). Assim como a temperatura, as características do solo também podem influenciar o crescimento da planta, podendo provocar o encurtamento e a diminuição do diâmetro das hastes resultando numa menor proporção destas (Vough \& Marten, 1971).

Existe uma relação inversa entre a maturidade e a qualidade (Fick \& Janson, 1990; Hall et al., 2000; Hintz \& Albrecht, 1991; Kalu \& Fick, 1983; Sanderson, 1992; Sulc et al., 1997), e devido a isso, a produtividade está, de maneira geral, inversamente relacionada com a qualidade da forragem (Buscagalia et al. 1994). Na alfafa, o maior acúmulo de forragem durante a maturação é de tecidos altamente lignificados situados na parte inferior das hastes e, consequentemente, o valor nutritivo da planta diminui conforme a produção aumenta (Christian, 1977).

A relação haste/folha é um fator qualitativo importante, pois além de influenciar o valor nutritivo da forragem, afeta também a seleção da dieta e o consumo pelos animais (Chacon \& Stobbs, 1976; Chacon et al., 1978; Forbes \& Coleman, 1993). O declínio na qualidade com o avanço da maturidade é associado principalmente com a maior proporção de hastes e menor proporção de folhas, e devido à senescência das folhas nas porções baixas e sombreadas do estande (Albrecht et al., 1987; Buxton e Hornstein, 1986; Fick \& Onstad, 1988; Hodgson, 1990; Sheaffer et al., 2000).

O número de cortes, o intervalo entre os cortes (Jung et al., 1996; Vaughn, 1990) e o método de pastejo além de influenciar na produção de forragem e na persistência, também influenciam na qualidade da planta (Allen et al., 1986; Smart, et al., 2001). O método de pastejo pode ter impacto sobre o valor nutritivo da forragem colhida pelos 
animais através de sua influência sobre a maturidade da planta e produção (Popp et al., 2000). O método de lotação contínua é caracterizado pela presença dos animais nas pastagens por períodos prolongados, enquanto que o método de lotação rotacionada é caracterizado por um período de pastejo seguido de um período de descanso (Hodgson, 1990). A produtividade da forragem e o desempenho animal estão relacionadas diretamente com as condições do dossel, que pode ser modificado de acordo com o método utilizado. $\mathrm{O}$ método de lotação contínua incentiva a alta densidade de perfilhos ou brotos levando a uma estabilidade do relvado. Isto ocorre quando é usada taxa de lotação variável para manter a quantidade de forragem constante, resultando na uniformidade do pastejo. O método de lotação rotacionada gera um período controlado de rebrota das plantas propiciado maior altura porém com menor densidade de perfilhos (Hodgson, 1990). Assim o método de pastejo influencia na qualidade da forragem devido ao seu efeito no número e tamanho de perfilhos (Parsons et al., 1983), diminuindo o florecimento e a relação haste/folha (Losada et al., 2000).

Ambos os métodos (lotação contínua e lotação rotacionada) têm como objetivo alta eficiência de utilização de forragem, que pode ser definida como sendo a proporção da forragem acumulada que é colhida pelos animais antes de senescer, garantindo assim a qualidade da forragem (Lemaire \& Chapman, 1996). Porém, no contexto de maximização do desempenho animal é necessário que haja o máximo consumo de nutrientes, que normalmente é atingido através de grandes ofertas maximizando assim a taxa de consumo que está relacionada com o tamanho e com a taxa de bocado (Hodgson, 1990; Popp et al., 2000). O manejo da desfolha aliada à taxa de lotação definirão a qualidade e a quantidade de nutrientes a serem ingeridos (Bertelsen et al., 1993; Popp et al., 2000; Williams \& Hammond, 1999).

O corte da alfafa no estádio de maturidade de pré-florescimento, geralmente aumenta a concentração de proteína bruta e eleva a qualidade total comparado ao de uma planta mais madura (Vaughn, 1990). Isto provavelmente ocorre devido à maior proporção de folhas na forragem jovens (Sheaffer et al, 2000) e é desejável dentro de um limite pois o uso de períodos curtos de rebrota deve ser homogenia para a longevidade 
do estande da alfafa e produção através do declínio dos teores e estoques de reservas nas raízes (Vaughn, 1990).

Diferenças de qualidade dentro de uma espécie podem ser explicadas por diferenças nas proporções de haste/folha. Existem casos, porém, onde não foram encontradas diferenças qualitativas entre as proporções haste/folha de materiais selecionados e de não selecionados para alta qualidade. Devido a isso, a qualidade da forragem nem sempre é facilmente entendida e explicada pela composição morfológica, pois além dela existem os fatores fisiológicos atuando na qualidade (Hall et al., 2000).

O funcionamento do sistema de produção sofre influência de vários fatores nutricionais, sanidade, genético, administrativo entre outros. A literatura ainda é escassa em relatos sobre o desempenho quantitativo e qualitativo de alfafa sob pastejo em regiões tropicais e também sobre o impacto econômico da adoção da alfafa pastejada em sistemas de produção animal. O estudo da alfafa sob pastejo em termos de produção e valor nutritivo ainda é incipiente para os genótipos em uso no nosso meio. Orientações sobre o manejo da pastagem procurando otimizar a utilização do pasto de alfafa maximizando o desempenho animal, deverão obrigatoriamente ser derivadas de estudos preliminares envolvendo avaliações agronômicas e qualitativas.

Assim, o objetivo do presente estudo foi avaliar a resposta produtiva e qualitativa de diferentes genótipos de alfafa, sendo quatro deles utilizados comercialmente em clima temperado e um adaptado as condições brasileiras, sob pastejo. Caracterizando os métodos e com isso as respostas da planta a cada situação imposta. 


\section{MATERIAL E MÉTODOS}

O trabalho foi desenvolvido no Departamento de Zootecnia da Escola Superior de Agricultura "Luiz de Queiroz", da Universidade de São Paulo, em Piracicaba, São Paulo (22 $42^{\prime} 30^{\prime \prime}$ latitude sul, $47^{\circ} 38^{\prime} 30^{\prime \prime}$ longitude oeste e $576 \mathrm{~m}$ de altitude).

O solo da área experimental é classificado como Nitossolo Vermelho Eutroférrico típico (Embrapa, 1999) ou Kandiudalfic Eutrudox (Soil Survey Staff, 1990). Em 18 de fevereiro de 2000 o solo foi amostrado a 20 e $40 \mathrm{~cm}$ e a análise revelou ausência de limitações de fertilidade (Tabela 1) não indicando a necessidade de correção. Em fevereiro de 2000 foi iniciado o preparo do solo.

Tabela 1. Resultado da análise química do solo da área experimental.

\begin{tabular}{|c|c|c|c|c|c|c|c|c|c|c|}
\hline Amostra & $\mathrm{PH}$ & M.O. & $\mathrm{P}$ & $\mathrm{K}$ & $\mathrm{Ca}$ & $\mathrm{Mg}$ & $\mathrm{H}+\mathrm{Al}$ & $S$ & $\mathrm{~T}$ & $\mathrm{~V}$ \\
\hline & $\left(\mathrm{Cl}_{2} \mathrm{Ca}\right)$ & $\mathrm{g} \mathrm{dm}^{-3}$ & $\mathrm{mgdm}^{-3}$ & ----- & $\mathrm{nmol}_{c} \mathrm{dl}_{1}$ & 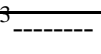 & & & & $\%$ \\
\hline $0-20$ & 6,3 & 40 & 88 & 9,6 & 103 & 34 & 20 & 147,1 & 166,8 & 87 \\
\hline $20-40$ & 6,2 & 29 & 64 & 8,1 & 88 & 29 & 22 & 125,2 & 146,9 & 85 \\
\hline
\end{tabular}

O clima de Piracicaba é classificado como Cwa, isto é, mesotérmico úmido subtropical de inverno seco, onde a temperatura do mês mais frio é inferior a $18^{\circ} \mathrm{C}$ e a do mês mais quente ultrapassa os $22^{\circ} \mathrm{C}$ (Brasil, 1960). Os dados climáticos referentes ao período experimental foram coletados no posto meteorológico do Departamento de Ciências Exatas da USP/ESALQ localizado a cerca de $500 \mathrm{~m}$ da área experimental. (Tabela 2). 
Tabela 2. Precipitação total e temperaturas médias mensais do ar (máxima, mínima e média) durante o período experimental.

\begin{tabular}{|c|c|c|c|c|}
\hline Mês & $\begin{array}{c}\text { Temperatura } \\
\text { Média }\end{array}$ & Precipitação Total & Irrigação & $\begin{array}{l}\text { Precipitação Total } \\
\text { Somado a Irrigação }\end{array}$ \\
\hline Março/2001 & 25,4 & 164,2 & 10 & 174,2 \\
\hline Média Março & 24,1 & 144,7 & & \\
\hline Abril/2001 & 24,7 & 24,1 & 46 & 70,1 \\
\hline Média Abril & 21,9 & 63,1 & & \\
\hline Maio/2001 & 19,2 & 60,6 & 35 & 98,1 \\
\hline Média Maio & 19,1 & 52,9 & & \\
\hline Junho/2001 & 18,5 & 19,9 & 26 & 45,9 \\
\hline Média (Junho) & 17,6 & 43,2 & & \\
\hline Julho/2001 & 17,7 & 27,2 & 39 & 66,2 \\
\hline Média (Julho) & 17,4 & 27,1 & & \\
\hline Agosto/2001 & 20,2 & 44,2 & 51 & 95,2 \\
\hline Média (Agosto) & 19,2 & 30,5 & & \\
\hline Setembro/2001 & 21,4 & 48,4 & 47 & 95,4 \\
\hline Média (Setembro) & 20,7 & 63,5 & & \\
\hline Outubro/2001 & 22,8 & 173,3 & 70 & 243,3 \\
\hline Média (Outubro) & 22,3 & 111,1 & & \\
\hline Novembro/2001 & 24,7 & 152,4 & 68 & 220,4 \\
\hline Média (Novembro) & 23,1 & 131,2 & & \\
\hline Dezembro/2001 & 24,0 & 204,2 & 35 & 239,2 \\
\hline Média (Dezembro) & 23,9 & 201,0 & & \\
\hline Janeiro/2002 & 24,5 & 320,2 & 3 & 323,2 \\
\hline Média (Janeiro) & 24,4 & 225,6 & & \\
\hline
\end{tabular}

Fonte: ESALQ, Departamento de Ciências Exatas ( Novembro 2002)

A área foi descompactada e em seguida arada, gradeada, e destorroada com enxada rotativa, para que fosse obtida uma estrutura do solo adequada para a semeadura. O rolo compactador foi utilizado para formar a cama das sementes.

O preparo das sementes foi realizado no Laboratório de Plantas Forrageiras do Departamento de Zootecnia da ESALQ. Para a semeadura de cada sub-parcela, as sementes foram pesadas em balança de precisão, seguindo uma taxa de semeadura de 12 $\mathrm{kg} \mathrm{ha}^{-1}$. Em seguida as sementes foram inoculadas com Shinorhizobium meliloti 
SEMIA-134 junto com 0,184 g de fungicida (Captan). A inoculação foi feita sobre superfície impermeável (sacos plásticos), umedecendo as sementes com água e açúcar (diluído a 1,0\%) com um borrifador em seguida misturando o inoculante com o fungicida. As sementes foram, então, secas em papel toalha e guardadas em saquinhos de papel. O contato do inoculante com o fungicida deveria ser mínimo e devido a isso, as sementes de cada bloco foram inoculadas ao mesmo tempo à noite e semeadas sempre no dia seguinte.

Para a semeadura foi definido um espaçamento entre linhas de $20 \mathrm{~cm}$ e com uma profundidade de cerca de $2 \mathrm{~cm}$. O processo foi demorado, tendo início no dia $27 \mathrm{de}$ agosto finalizando no dia 01 de setembro de 2000. A semeadura foi realizada por blocos e após a colocação das sementes no campo, os sulcos foram cobertos com solo e sofreram leve compactação.

A semeadura da alfafa na primavera não é indicada devido ao problema de competição com as ervas daninhas, o que pode prejudicar o estabelecimento do estande. Em 19 de setembro de 2000 foi feita aplicação do graminicida Verdict, haloxyfopmethyl [metil 2-\{4 (3-cloro-5-(trifluorometil-2-piridinoxi)) fenoxi\}-propanoato], 0,09 a $0,12 \mathrm{~kg}$ ia ha- ${ }^{-1}$, juntamente com óleo mineral Joint ${ }^{\circledR}$ a $0,25 \%$, nas parcelas. A manutenção entre as parcelas foi realizada com controle das ervas daninhas através do uso de herbicida glyphosate [N-(fosfonometil) glicina] pulverizado na forma de solução a $3 \% \mathrm{v} / \mathrm{v}$, e/ou corte com roçadeira costal.

Em 28 de novembro de 2000, cerca de 80 dias após a semeadura, foi realizado um corte de uniformização com uma segadora utilizada no corte para feno, a $7 \mathrm{~cm}$ do solo. O material cortado foi removido. Em 6 de dezembro de 2000 a área recebeu aplicação de micronutrientes (FTE BR 12) e húmus de minhoca, nas quantidades de 40 e $400 \mathrm{~kg} \mathrm{ha}^{-1}$ respectivamente. Em fevereiro de 2001 foram montadas as cercas elétricas ao redor das parcelas.

Em 23 de fevereiro de 2001 houve outro corte na área experimental, à altura média de $5 \mathrm{~cm}$. Em 20 de março de 2001 foi feita outra aplicação do graminicida Verdict, juntamente com óleo mineral Joint ${ }^{\circledR}$ a 0,25 \%. Em 17 de julho de 2001 devido 
à infestação da área pelo pulgão-verde-azulado [Acyrthosiphon kondoi (Shinji, 1938)] aplicou-se Boveril PM (Beauveria bassiana) como controle biológico $4 \mathrm{~kg} \mathrm{ha}^{-1}$.

Um sistema de irrigação por aspersão foi montado no início de março 2000. Durante o experimento a irrigação era realizada quando necessário devido ao monitoramento por pluviômetros e tensiômetros da área, sendo que os dados estão descritos na Tabela 2.

O delineamento utilizado foi o de blocos completos casualizados com parcelas subdivididas (split-splot), com dez tratamentos e seis repetições de campo, totalizando 60 unidades experimentais. A área apresenta aproximadamente $1.700 \mathrm{~m}^{2}$ na qual foram implantados os seis blocos com $147 \mathrm{~m}^{2}(7 \times 21 \mathrm{~m})$. Cada bloco foi dividido em duas parcelas de $73,5 \mathrm{~m}^{2}(7 \times 10,5 \mathrm{~m})$ e sendo que cada parcela foi dividida em cinco subparcelas de $14,7 \mathrm{~m}^{2}(2,1 \times 7,0 \mathrm{~m})$. Nas parcelas foram alocadas os métodos de pastejo e nas subparcelas os cinco genótipos.

Os genótipos foram escolhidos de modo a representar uma gama de combinações entre três fatores que afetam o desempenho das plantas (Tabela 3).

Tabela 3. Combinações dos fatores considerados para a escolha dos genótipos.

\begin{tabular}{lccc}
\hline Genótipo & $\begin{array}{c}\text { Dormência } \\
(\mathrm{GD})\end{array}$ & Procedência & $\begin{array}{c}\text { Tolerância ao } \\
\text { pastejo }\end{array}$ \\
\hline ABT 805 & 8 & $\mathrm{I}$ & $\mathrm{T}$ \\
Alfagraze & 2 & $\mathrm{I}$ & $\mathrm{T}$ \\
Crioula & 9 & $\mathrm{~N}$ & $\mathrm{NT}$ \\
CUF 101 & 9 & $\mathrm{I}$ & $\mathrm{NT}$ \\
Pioneer 5432 & 4 & $\mathrm{I}$ & $\mathrm{T}$ \\
GD= grau de dormência (1=totalmente dormente - II=totalmente não dormente); $\mathrm{N}=$ Nacional; $\mathrm{I}=$ Importado; $\mathrm{T}=$ \\
Tolerante; NT = Não tolerante.
\end{tabular}

Os métodos de pastejo adotados procuraram simular a lotação rotacionada e a lotação contínua. O pastejo rotacionado teve período de descanso de 28 dias no verão e 42 dias no inverno e a lotação contínua foi simulada com pastejo a cada 7 dias. Onde o verão consistiu o intervalo entre as datas de 31 de março a 26 de maio de 2001 e 24 de 
novembro de 2001 a 19 de janeiro de 2002 , e o inverno entre 7 de julho a 27 de outubro de 2001.

Os pastejos foram feitos por lotes de novilhas da raça holandesa preto-branco com idade entre 12 a 18 meses e com peso médio de 300 a $450 \mathrm{~kg}$. Durante o período experimental foram totalizados 43 pastejos para o tratamento de lotação contínua e 10 para o tratamento rotacionado, utilizando a técnica de mob-grazing até uma altura residual de aproximadamente $7 \mathrm{~cm}$ em todos os tratamentos.

A massa de forragem (MF) foi medida em cada unidade experimental imediatamente antes e imediatamente após cada pastejo usando-se a técnica de dupla amostragem (Pedreira, 2002) usando o prato ascendente como medida indireta. As amostragens não destrutivas constituíam-se de 30 leituras por unidade experimental a cada evento de amostragem. A dupla amostragem consiste em escolher em cada unidade experimental, antes e depois do pastejo, dois pontos que, visualmente, representassem a máxima e a mínima MF. Esses locais eram demarcados com um circulo de $\sim 0,25 \mathrm{~m}^{2}$, medidos com o prato ascendente e em seguida cortado a três $\mathrm{cm}$ de altura, com a forragem levada para estufa de ar forçado a $65^{\circ} \mathrm{C}$ até peso constante. Com as leituras feitas com o prato ascendente pré e pós-pastejo foi possível calcular a massa de forragem (MF) substituindo $\mathrm{h}$ pela média das 30 medições de cada parcela em cada evento de amostragem. Com os valores de MF o acúmulo de forragem (AF) em cada rebrota foi calculado subtraindo da MF pré pastejo do ciclo "n", a MF pós pastejo do ciclo " $n$ 1". As taxas médias diárias de AF foram calculadas dividindo-se o AF pelo número de dias de acúmulo em cada rebrota. As amostragens destrutivas (ou amostragem dupla, para calibração do prato) foram feitas em 4 datas ao longo do período experimental: em 24 de março de 2001; 24 de maio de 2001; 27 de outubro de 2001 e 20 de dezembro de 2001 totalizando de 120 locais de dupla amostragem. Também, foram coletados dados de altura do dossel antes da medida de massa de forragem pré e pós pastejo.

Para a caracterização qualitativa de forragem pastejada, as amostras foram coletadas nos dias 23 de março, 25 de maio, 18 de agosto, 25 de outubro e 20 de dezembro de 2001. Nessas ocasiões, a forragem foi cortada a $7 \mathrm{~cm}$ do solo em pontos 
aleatórios da parcela sob lotação rotacionada, cortando-se porções representativas do horizonte a ser pastejado. Para a lotação contínua, a forragem foi colhida de forma a simular a colheita de forragem pelos animais. As amostras foram levadas ao laboratório e sub-amostrada. Uma sub-amostra foi levada imediatamente à estufa de ar forçado a 65 ${ }^{\circ} \mathrm{C}$ até peso constante, e a outra foi separada em haste e folhas. A fração "haste" consistia em hastes propriamente ditas, pecíolos e inflorescências, quando presentes. A porção da folha consistia nos três peciólulos e os seus respectivos folíolos. Após a separação, todas as sub-amostras foram secas em estufa de ar forçado a $65^{\circ} \mathrm{C}$ até peso constante, pesadas, e moídas em moinho de faca tipo Wiley com peneira de abertura de $1 \mathrm{~mm}$.

Todas as amostras foram analisadas para determinação das concentrações de proteína bruta (PB), fibra em detergente neutro (FDN), fibra em detergente ácido (FDA) e lignina, além da digestibilidade in vitro da matéria seca (DIVMS) usando espectroscopia do infravermelho proximal (NIRS). Para tanto, o espectro de cada amostra foi coletado em equipamento Foss NIRSystem (Near Infrared Reflectance Spectroscopy), modelo 5000. A amplitude de detecção utilizada foi entre 1100 e 2500 $\mathrm{nm}$ de comprimento de onda. Os programas CENTER e SELECT foram utilizados para identificar as amostras a serem analisadas para a calibração do aparelho, onde foram selecionadas 90 das 528 amostras. Nessas 90 amostras, a análise de PB foi realizada pelo do Sistema de Determinador de N FP-528 (610-700-300, LECO Corp., St. Joseph, Michigan, EUA). As análises de FDN, FDA e lignina foram feitos de acordo com os métodos descritos por Robertson \& Van Soest (1981). A DIVMS foi estimada de acordo com o método descrito por Tilley \& Terry (1963) e os valores finais foram ajustados de acordo com NRC Gado de Leite (2001) em 7 unidades a menos, devido a superestimação do método. Os dados de composição químico-bromatológica foram inseridos no programa do NIRS e através do programa CALIBRATE foram obtidas equações de regressões que converteram os dados de espectro do NIRS em concentrações de MS, PB, FDN, FDA e lignina, além da DIVMS.

Os dados foram analisados utilizando-se o procedimento MIXED do pacote estatístico SAS ${ }^{\circledR}$, Statistical Analysis System, (Littell et al., 1996). As médias de 
produção foram obtidas pelo método dos quadrados mínimos (LSMEANS), e para efeito de comparação de médias entre tratamentos foi utilizado o teste de Tukey com um nível de significância de 5\%. As interações significativas foram desdobradas de acordo com os fatores envolvidos para as épocas nas variáveis onde houve significância. Na análise dos dados de valor nutritivo foi necessário combinar repetições de campo uma vez que, em função do procedimento de amostragem, cada repetição fornecia uma quantidade insuficiente de material para as análises laboratoriais. A solução adotada foi agrupar três repetições de campo em uma, resultando em duas repetições ao invés de seis. Para a análise estatística o mesmo foi feito com o método de lotação rotacionada. A obtenção das médias foi realizada através da utilização do método dos quadrados mínimos (LSMEANS), e para efeito de comparação de médias entre tratamentos foi utilizado o teste de Tukey com um nível de significância de $10 \%$. 


\section{RESULTADOS E DISCUSSÃO}

\subsection{Produtividade e distribuição estacional da produção de forragem}

O acúmulo de forragem total (AFT) sofreu influência do método de pastejo $(P=0,0001)$, genótipo $(P=0,0071)$ e, também, da interação método $\times$ genótipo $(P=0,0001)$.

Tabela 4. Acúmulo de forragem total de genótipos de alfafa sob pastejo, ao longo do período experimental.

\begin{tabular}{lcc}
\hline Genótipo & Lotação contínua & Lotação rotacionada \\
\hline & $---1,-1,6^{\mathrm{Aa}}$ & $17,6^{\mathrm{Ab}}$ \\
ABT 805 & $26,3^{\mathrm{Aa}}$ & $13,3^{\mathrm{Bb}}$ \\
Alfagraze & $19,9^{\mathrm{Bb}}$ & $18,3^{\mathrm{Ab}}$ \\
Crioula & $19,4^{\mathrm{Bb}}$ & $17,7^{\mathrm{Ab}}$ \\
CUF 101 & $24,3^{\mathrm{Aa}}$ & $15,3^{\mathrm{Bb}}$ \\
Pioneer 5432 & &
\end{tabular}

EPM $=939,2705$

${ }^{\mathrm{AB}}$ Médias na coluna seguidas de mesmas letras maiúsculas não diferem entre si $(\mathrm{P}>0,05)$.

${ }^{a b}$ Médias na linha seguidas de mesmas letras minúsculas não diferem entre si $(\mathrm{P}>0,05)$.

O período experimental foi dividido em duas estações: o verão compreendeu 70, $2 \%$ (192 dias) e o inverno 29,8\% (81 dias) do período total. O acúmulo de forragem de verão (AFV) foi medido de 31 de março até 30 de junho 2001 e de 11 de outubro de 2001 até 18 de janeiro 2002, e foi afetado por método $(P=0,0306)$, genótipo $(P=0,0001)$ 
e pela interação método $\times$ genótipo $(P=0,0001)$. Entre 9 de julho e 28 de setembro de 2001, foi medido o acúmulo de forragem de inverno (AFI), o qual sofreu efeito de método $(P=0,0001)$ e da interação método $\times$ genótipo $(P=0,0179)$, mas não de genótipo $(P=0,1153)$.

Tabela 5. Acúmulo de forragem de verão (AFV) e acúmulo de forragem de inverno (AFI) em genótipos de alfafa sob pastejo.

\begin{tabular}{lcccc}
\hline Genótipo & \multicolumn{2}{c}{ Verão } & \multicolumn{2}{c}{ Inverno } \\
& Lot. Contínua & Lot. Rotacionada & Lot. Contínua & Lot. Rotacionada \\
\hline \multirow{2}{*}{ ABT 805 } & $18,9^{\mathrm{Aa}}$ & $14,3^{\mathrm{Ab}}$ & $7,6^{\mathrm{Aa}}$ & $3,3^{\mathrm{Ab}}$ \\
Alfagraze & $18,8^{\mathrm{Aa}}$ & $10,6^{\mathrm{Cb}}$ & $7,4^{\mathrm{Aa}}$ & $2,7^{\mathrm{Bb}}$ \\
Crioula & $12,8^{\mathrm{Ca}}$ & $14,7^{\mathrm{Aa}}$ & $7,2^{\mathrm{Aa}}$ & $3,6^{\mathrm{Ab}}$ \\
CUF 101 & $12,2^{\mathrm{Ca}}$ & $14,3^{\mathrm{Aa}}$ & $7,3^{\mathrm{Aa}}$ & $3,4^{\mathrm{Ab}}$ \\
Pioneer 5432 & $16,6^{\mathrm{Ba}}$ & $12,6^{\mathrm{Bb}}$ & $7,7^{\mathrm{Aa}}$ & $3,2^{\mathrm{Ab}}$ \\
\hline
\end{tabular}

$\mathrm{EPM}=852,2324$

${ }_{\mathrm{AB}}$ Médias na coluna seguidas de mesmas letras maiúsculas não diferem entre si ( $\left.\mathrm{P}>0,05\right)$.

${ }^{a b}$ Médias na linha, dentro de época, seguidas de mesmas letras minúsculas não diferem entre si $(\mathrm{P}>0,05)$.

A taxa média diária de acúmulo de forragem no verão (TMDAV), respondeu aos efeitos de método $(P=0,0011)$, genótipo $(P=0,0001)$ e da interação método $\times$ genótipo $(P=0,0001)$. A taxa média diária de acúmulo de inverno (TMDAI) sofreu efeito de método $(P=0,0001)$ e da interação método $\times$ genótipo $(P=0,0124)$, não sendo verificado efeito de genótipo $(P=0,1019)$ (Tabela 7). 
Tabela 6. Proporção dos acúmulos de forragem de verão (AFV) e de inverno (AFI) em alfafa sob pastejo em relação ao acúmulo de forragem total (AF) do período experimental.

\begin{tabular}{lcccc}
\hline Genótipo & \multicolumn{2}{c}{ Verão } & \multicolumn{2}{c}{ Inverno } \\
& Lot. Contínua & Lot. Rotacionada & Lot. Contínua & Lot. Rotacionada \\
\hline \multirow{2}{*}{ ABT 805 } & $---0^{\mathrm{A}}$ & $81,2^{\mathrm{A}}$ & $28,6^{\mathrm{C}}$ & $18,7^{\mathrm{C}}$ \\
Alfagraze & $71,5^{\mathrm{A}}$ & $79,7^{\mathrm{C}}$ & $28,1^{\mathrm{C}}$ & $20,3^{\mathrm{A}}$ \\
Crioula & $64,3^{\mathrm{C}}$ & $80,3^{\mathrm{B}}$ & $36,0^{\mathrm{A}}$ & $19,7^{\mathrm{B}}$ \\
CUF 101 & $62,9^{\mathrm{C}}$ & $80,8^{\mathrm{B}}$ & $37,5^{\mathrm{A}}$ & $19,2^{\mathrm{B}}$ \\
Pioneer 5432 & $68,3^{\mathrm{B}}$ & $82,3^{\mathrm{A}}$ & $31,8^{\mathrm{B}}$ & $20,9^{\mathrm{A}}$ \\
\hline
\end{tabular}

$\mathrm{EPM}=288,2018$

${ }^{\mathrm{AB}}$ Médias na coluna seguidas de mesmas letras maiúsculas não diferem entre si $(\mathrm{P}>0,05)$.

Tabela 7. Taxa média diária de acúmulo de forragem no verão (TMDAV) e taxa média diária de acúmulo de inverno (TMDAI).

\begin{tabular}{lcccc}
\hline Genótipo & \multicolumn{2}{c}{ Verão } & \multicolumn{2}{c}{ Inverno } \\
& Lot. Contínua & Lot. Rotacionada & Lot. Contínua & Lot. Rotacionada \\
\hline \multirow{2}{*}{ ABT 805 } & $139,09^{\mathrm{Aa}}$ & $92,07^{\mathrm{Ab}}$ & $93,82^{\mathrm{Aa}}$ & $40,98^{\mathrm{Ab}}$ \\
Alfagraze & $137,60^{\mathrm{Aa}}$ & $69,61^{\mathrm{Cb}}$ & $91,21^{\mathrm{Aa}}$ & $33,64^{\mathrm{Bb}}$ \\
Crioula & $104,46^{\mathrm{Ca}}$ & $95,99^{\mathrm{Aa}}$ & $88,73^{\mathrm{Ba}}$ & $44,92^{\mathrm{Ab}}$ \\
CUF 101 & $101,59^{\mathrm{Ca}}$ & $92,80^{\mathrm{Aa}}$ & $89,86^{\mathrm{Ba}}$ & $42,15^{\mathrm{Ab}}$ \\
Pioneer 5432 & $127,51^{\mathrm{Ba}}$ & $80,19^{\mathrm{Bb}}$ & $95,60^{\mathrm{Aa}}$ & $40,11^{\mathrm{Ab}}$ \\
\hline
\end{tabular}

EPM de verao $=4,8757$ inverno $=3,6979$

${ }^{\mathrm{AB}}$ Médias na coluna seguidas de mesmas letras maiúsculas não diferem entre si ( $\left.\mathrm{P}>0,05\right)$.

${ }^{\text {ab }}$ Médias na linha, dentro de época, seguidas de mesmas letras minúsculas não diferem entre si ( $\left.\mathrm{P}>0,05\right)$.

Segundo Smith et al. (2000), os cultivares desenvolvidos para tolerância ao pastejo têm sido associados com baixas produtividades devido æ̀̀ suas características agronômicas e morfológicas, como hábito de crescimento decumbente e alto grau de dormência. Kallenbach et al. (2002), confirmaram a afirmação de Smith et al. (2000), e 
mostraram que Pioneer 5373 (cultivar moderno resistente a várias pragas, não tolerante ao pastejo) apresentou produção superior à de Alfagraze $\left(10,1\right.$ e 9,6 $\mathrm{Mg} \mathrm{ha}^{-1} \mathrm{ano}^{-1}$, respectivamente) durante três anos de avaliação sob corte. Porém, Smith et al. (1989) avaliaram cultivares de alfafa, incluindo a GA-GC (atualmente Alfagraze) sob lotação contínua, concluindo que os cultivares destinados a feno apresentaram altas taxas de mortalidade, prejudicando a rebrota e reduzindo a produtividade, o mesmo não acontecendo com os cultivares tolerantes ao pastejo. Nesse último estudo, o GA-GC manifestou um bom potencial de rebrota e persistência sob pastejo, produzindo $6.370 \mathrm{~kg}$ $\mathrm{ha}^{-1}$ durante os 114 dias correspondente ao período de verão. Smith \& Bouton (1993) reportaram produtividade média da Alfagraze de 7,6 $\mathrm{Mg} \mathrm{ha}^{-1} \mathrm{ano}^{-1}$ sob lotação contínua. $\mathrm{O}$ presente trabalho explorou a capacidade dos genótipos tolerantes e não-tolerantes ao pastejo foi constatado que os genótipos tolerantes apresentaram produção superior a reportada na literatura.

Crioula e CUF 101 apresentaram produção semelhante a que é reportado na literatura nacional. Alvim \& Botrel (1995), estudando o desempenho produtivo de alfafa Crioula na Zona da Mata de Minas Gerais mediram produções de 10 a $20 \mathrm{Mg} \mathrm{ha}^{-1} \mathrm{ano}^{-1}$. Monteiro et al. (1998) avaliaram 17 cultivares em Marechal Cândido Rondon, PR obtendo produção média de $12,1 \mathrm{Mg} \mathrm{ha}^{-1} \mathrm{ano}^{-1}$, sendo que entre os cultivares avaliados estavam Crioula (12,8 $\left.\mathrm{Mg} \mathrm{ha}^{-1} \mathrm{ano}^{-1}\right)$ e CUF 101 (13,1 $\left.\mathrm{Mg} \mathrm{ha}^{-1} \mathrm{ano}^{-1}\right)$. Viana et al. (1998) estudando 28 cultivares de alfafa no cerrado de Sete Lagoas, MG, observaram que a Crioula foi a mais produtiva (20 Mg ha- $\mathrm{ano}^{-1}$ ). Ruggieri et al. (2002), num experimento de cultivares de alfafa para produção de feno, mediram produções anuais médias de 21,3 e 20,9 Mg MS ha ${ }^{-1}$ ano $^{-1}$ para Crioula importada e Crioula CRA-RS, respectivamente. Da Silva et al. (2002), obtiveram em 13 cortes durante 18 meses, produções de forragem de 22,7; 21,6 e 20,1 Mg MS ha-1 ano $^{-1}$, para Crioula importada, Crioula CRA-RS e Crioula Honda, respectivamente.

Quanto à estacionalidade, ABT-805 e Alfagraze, sob lotação contínua, não diferiram. Pioneer 5432 apresentou-se na posição intermediária e Crioula e CUF-101 apresentaram a mesma distribuição estacional. Sob lotação rotacionada, ABT-805 e Pioneer 5432 tiveram estacionalidade mais acentuada que Crioula e CUF-101, enquanto 
Alfagraze foi a menos estacional. É importante observar que a definição de "verão" e "inverno" neste trabalho não segue as estações do ano. $\mathrm{O}$ verão, devido aos contratempos ocorridos no início do experimento, foi prolongado até o mês de junho, o que na verdade seria o inverno agrostológico. $\mathrm{O}$ ano de 2000 teve um inverno mais quente que a média dos últimos 84 anos e devido à definição das estações adotadas neste experimento a comparação de estacionalidade com outros trabalhos publicados pode ser indevida.

Ruggieri et al. (2002) reportaram, no entanto, estacionalidade na produção de alfafa semelhante à encontrada no presente estudo, sendo que as produções no inverno foram de 2,4 $\mathrm{Mg} \mathrm{ha}^{-1}$ para a Crioula importada e de 2,4 $\mathrm{Mg} \mathrm{ha}^{-1}$ para a Crioula CRA-RS. Botrel et al. (2002), avaliaram cultivares sob corte em diferentes regiões do estado de Minas Gerais, relataram para Crioula produção anual em torno de $13 \mathrm{Mg} \mathrm{MS} \mathrm{ha-1}$ ano $^{-1}$ na Zona da Mata, com 31,1\% da produção anual durante o inverno; 17,56 Mg MS $\mathrm{ha}^{-1} \mathrm{ano}^{-1}$, no Sul de Minas com 51,9\% no inverno e de $20 \mathrm{Mg} \mathrm{MS} \mathrm{ha}^{-1} \mathrm{ano}^{-1}$ na Zona Metalúrgica com 43,8\% distribuído no inverno. Diferentemente, Oliveira (2001) estudando a produtividade e o valor nutritivo de cultivares de alfafa mantidos sob irrigação, obteve produtividade média de $21 \mathrm{Mg} \mathrm{MS} \mathrm{ha}{ }^{-1} \mathrm{ano}^{-1}$ e estacionalidade média de produção para alfafa Crioula Chilena de 59 e $41 \%$ para os meses de verão e inverno, respectivamente. Monteiro et al. (1998) relataram uma estacionalidade média de produção com 35,5\% no inverno, para dezessete cultivares avaliados.

As TMDAI foram iguais ou semelhantes às TMDAV (Tabela 7) considerando o método de pastejo. Isto pode estar relacionado com o período de inverno ( 9 de julho a 28 de setembro de 2001), que foi mais quente (agosto $/ 20,2^{\circ} \mathrm{C}$; setembro $/ 21,4^{\circ} \mathrm{C}$ ) que o normal (agosto $/ 19,2^{\circ} \mathrm{C}$; setembro $/ 20,7^{\circ} \mathrm{C}$ ), na localidade do experimento, favorecendo a produção dos genótipos dormentes como Alfagraze e Pioneer 5432. Esses genótipos provavelmente não entraram em dormência, como seria de se esperar em invernos rigorosos, produzindo área foliar durante o inverno se comportando mais como genótipos não dormentes.

Monteiro (1989), trabalhando em Piracicaba com CUF-101 e Crioula, relatou que, quando as temperaturas médias do inverno se mantiveram mais baixas dentro do 
período experimental, os cultivares responderam de maneira similar ao manejo da desfolha, enquanto que, após o aumento da temperatura, com média de $24^{\circ} \mathrm{C}$, a resposta foi diferente quanto à capacidade de rebrota e a produção de forragem. No presente estudo, os mesmos genótipos sob pastejo, tiveram desempenho semelhante, com AFT em torno de $20 \mathrm{Mg} \mathrm{ha}^{-1}$ sob lotação contínua e de $18 \mathrm{Mg} \mathrm{ha}^{-1}$ sob lotação rotacionada.

Comparando os genótipos, dentro do método de pastejo rotacionado, nota-se os não tolerantes ao pastejo produziram mais que os tolerantes, com exceção de ABT 805. Dados de altura do dossel, apesar de não terem sido analisados estatisticamente, revelaram que os genótipos tolerantes apresentaram, numericamente, menor altura prépastejo (33 a $38 \mathrm{~cm}$ ), porém com alta densidade de hastes por coroa (avaliação visual) no estande em comparação com os genótipos não tolerantes que apresentaram maior altura (49 a $55 \mathrm{~cm}$ ) com densidade de hastes por coroa aparentemente menor. Isso indica que, apesar da alta densidade de hastes por coroa, a altura menor determinou menor produção de massa de forragem. ABT 805 foi o único genótipo tolerante que apresentou produção igual aos genótipos não tolerantes, o que pode ser explicado pela compensação da sua altura mediana pré-pastejo (média de $44 \mathrm{~cm}$ ), comparada com Alfagraze e Pioneer, aliada a alta densidade de hastes por coroa.

Os acúmulos de forragem e as taxas médias diárias de acúmulo de forragem, foram sempre superiores sob lotação contínua do que sob lotação rotacionada. Alfagraze, Pioneer 5432 e ABT-805 acumularam respectivamente, sob lotação contínua 49,4 e 34\% mais forragem em comparação com Crioula e CUF-101 que foi de 8\%, para ambos genótipos.

Genótipos tolerantes apresentaram produtividade superior à dos não tolerantes. Isto, provavelmente, ocorreu devido ao favorecimento dos genótipos tolerantes que obtiveram uma maior TMDA tanto de inverno como de verão, mostrando o seu potencial de rebrota sob lotação contínua. Sob lotação rotacionada os genótipos tiveram TMDA semelhante, porém, inferior ao TMDA da lotação contínua. O período de rebrota estipulado para a lotação rotacionada foi de quatro e seis semanas (verão e inverno, respectivamente), tentando simular pastejo rotacionado, a fim de garantir que a maturidade da planta para o pastejo. A recomendação é que os cortes devam ocorrer 
sempre que 50\% das flores estiverem abertas (Dall'Agnol \& Scheffer-Basso, 2000). Isso ocorreu em todos os pastejos de lotação rotacionada, onde algumas plantas chegaram a apresentar sementes em observações feitas durante a amostragem de MF. A forragem, quando colhida em estádio de florescimento, teve sua TMDA de forragem diluída durante o período de descanso influenciando, assim, o AF total. O mesmo resultado foi obtido por Botrel et al. (1996) onde a maior produção de forragem foi conseguido em um intervalo entre cortes de 28 dias, pois aos 42 e 49 dias as plantas apresentavam em estádios de florecimento e florecimento pleno, respectivamente.

Todos genótipos apresentaram produtividade superior ou igual à reportada na literatura, e tanto os genótipos não tolerantes quanto os tolerantes, apresentaram resistência ao pastejo. Ficou evidente a plasticidade da alfafa na região de Piracicaba, apesar do curto período de avaliação.

\subsection{Composição morfológica de genótipos de alfafa sob pastejo}

A proporção de folhas foi afetada por método $(\mathrm{P}=0,0356)$ e estação $(P=0,0014)$, além da interação método $\times$ estação $(P=0,0004)$.

Tabela 8. Porcentagem de folha em forragem de alfafa em resposta ao método de pastejo e àestação.

\begin{tabular}{|c|c|c|c|}
\hline Método de Pastejo & Verão & Inverno & $\overline{\text { EPM }}$ \\
\hline & \multicolumn{3}{|c|}{ 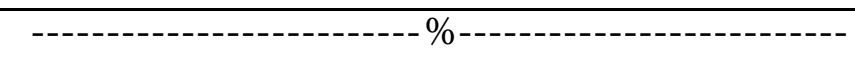 } \\
\hline Lotação contínua & $57,4^{\mathrm{Ab}}$ & $65,4^{\mathrm{Aa}}$ & 0,9611 \\
\hline Lotação rotacionada & $50,2^{\mathrm{Ba}}$ & $49,7^{\mathrm{Ba}}$ & 0,8438 \\
\hline
\end{tabular}

A proporção de hastes foi afetada por método $(P=0,0356)$, estação $(P=0,0014)$, além do efeito da interação método $\times$ estação $(P=0,0004)$ 
Tabela 9. Porcentagem de haste em forragem de alfafa em resposta ao método de pastejo e à estação.

\begin{tabular}{|c|c|c|c|}
\hline Método de Pastejo & Verão & Inverno & $\overline{\mathrm{EPM}}$ \\
\hline & \multicolumn{3}{|c|}{ (---- } \\
\hline Lotação contínua & $42,6^{\mathrm{Ba}}$ & $34,5^{\mathrm{Bb}}$ & 0,9611 \\
\hline Lotação rotacionada & $49,7^{\mathrm{Aa}}$ & $50,2^{\mathrm{Aa}}$ & 0,8438 \\
\hline
\end{tabular}

A resposta da forragem ao método de pastejo foi caracterizada pelo estádio de desenvolvimento. Sob lotação contínua a forragem era pastejada sempre no início da rebrota e a alfafa encontrava-se em estádio vegetativo. Devido a esta característica a amostra coletada era composta de folhas e hastes jovens. Já sob lotação rotacionada a forragem era pastejada em estádio avançado de maturidade com florescimento.

Assim como o método, a estação deveria ter influenciado na composição morfológica (Nelson e Moser, 1994) entretanto não houve diferença. Isto provavelmente ocorreu devido ao inverno mais quente no ano de 2001 e também pela irrigação, apesar da produção no verão ter sido visivelmente superior ao inverno em ambos métodos de pastejo.

Os dados do presente trabalho são similares ao encontrado na literatura, sendo que sob lotação contínua há uma maior porcentagem de folhas que sob lotação rotacionada. A maturidade da planta é outro fator que afeta a morfologia e, consequentemente, o valor nutritivo. Sigh \& Winch (1974), analisaram a morfologia de dois cultivares de alfafa, Vernal e Saranac, em diferentes sistemas de corte. A forragem foi avaliada através da quantidade de hastes por planta e por corte. Sendo que a forragem cortada no estádio vegetativo (pré-florescimento) apresentou menor número de hastes (5,4 hastes por corte) que no início de florescimento (7,5 hastes por corte), entretanto o número de hastes decresceu para a forragem cortada no estádio de florescimento total. Sheaffer et al. (2000) relataram o decréscimo na porcentagem de folhas (de 517,3 para $458 \mathrm{~g} \mathrm{~kg}^{-1} \mathrm{MS}$ ) com o aumento da maturidade da alfafa. $\mathrm{O}$ mesmo resultado foi obtido por Alberecht et al. (1987) onde a relação folha/haste decresceu de 1,45 a 0,70 do 
estádio vegetativo ao estádio inicial de produção de sementes, respectivamente. $\mathrm{O}$ decréscimo na relação folha/haste é o resultado do aumento de hastes e a senescência e abscisão das folhas localizadas na porção inferior da planta. Nordkvist e Åman (1986) reportaram o aumento na porcentagem de hastes de 18,5 a 50,7 \% sendo que a porcentagem das folhas decresceu de 72,9 a $18,4 \%$ durante o período em que a forragem acumulou de 800 a $11000 \mathrm{~kg} \mathrm{ha}^{-1}$, equivalente a três meses (maio a agosto).

\subsection{Valor nutritivo de genótipos de alfafa sob pastejo}

\subsubsection{Digestibilidade in vitro da matéria seca de alfafa sob pastejo}

A digestibilidade in vitro da matéria seca (DIVMS) para planta inteira foi afetada por método $(P=0,0540)$ e estação $(P=0,0001)$. Forragem produzida sob lotação contínua apresentou maior DIVMS $\left(810,7 \mathrm{~g} \mathrm{~kg}^{-1}\right)$, do que sob lotação rotacionada $\left(757,9 \mathrm{~g} \mathrm{~kg}^{-1}\right) \mathrm{e}$ a forragem de verão teve menor DIVMS, $\left(773,7 \mathrm{~g} \mathrm{~kg}^{-1}\right)$ que no inverno $\left(794,9 \mathrm{~g} \mathrm{~kg}^{-1}\right)$.

A DIVMS das folhas sofreu apenas o efeito da interação tripla sob lotação contínua (Tabela 4.5).

Tabela 10. Valores de digestibilidade in vitro da matéria seca (DIVMS) da folha de alfafa sob lotação contínua no verão e no inverno.

\begin{tabular}{lcc}
\hline Genótipo & \multicolumn{2}{c}{ Lotação contínua } \\
& Verão & Inverno \\
\hline ABT 805 & $755,70^{\mathrm{Bb}}$ & $769,30^{\mathrm{Aa}}$ \\
Alfagraze & $779,90^{\mathrm{Aa}}$ & $759,00^{\mathrm{Bb}}$ \\
Crioula & $786,97^{\mathrm{Aa}}$ & $756,32^{\mathrm{Bb}}$ \\
CUF 101 & $752,10^{\mathrm{Bb}}$ & $780,07^{\mathrm{Aa}}$ \\
Pioneer 5432 & $767,45^{\mathrm{Aa}}$ & $768,90^{\mathrm{Aa}}$ \\
\hline
\end{tabular}

$\mathrm{EPM}=4.1143$

${ }^{\mathrm{AB}}$ Médias na coluna seguidas de mesmas letras maiúsculas não diferem entre si $(\mathrm{P}>0,10)$.

${ }^{\mathrm{ab}}$ Médias na linha seguidas de mesmas letras minúsculas não diferem entre si $(\mathrm{P}>0,10)$. 
Sob lotação rotacionada as DIVMS de folhas no inverno $\left(776 \mathrm{~g} \mathrm{~kg}^{-1}\right)$ e verão (770,2 $\mathrm{g} \mathrm{kg}^{-1}$ ) foram iguais, assim como foram entre genótipos.

A haste apresentou diferentes DIVMS nos métodos de pastejo $(P=0,0379)$, estação $(P=0,0001)$ além do efeito da interação entre método $\times$ estação $(P=0,0001)$.

Tabela 11. Valores de DIVMS da haste nos métodos de pastejo dentro das estações de verão e inverno.

\begin{tabular}{|c|c|c|c|}
\hline Método de pastejo & Verão & Inverno & EPM \\
\hline & & $-\mathrm{g} \mathrm{kg}^{-1}$ & 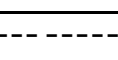 \\
\hline Lotação contínua & $676,14^{\mathrm{Ab}}$ & $759,48^{\mathrm{Aa}}$ & 7,006 \\
\hline Lotação rotacionada & $576,11^{\mathrm{Ba}}$ & $570,52^{\mathrm{Ba}}$ & 7,006 \\
\hline
\end{tabular}

Os genótipos não mostraram diferença quanto à DIVMS da forragem porém o método de pastejo mostrou-se ser determinante para a colheita de forragem total de bom valor nutritivo. Botrel et al. (1996) estudaram o valor nutritivo da alfafa Crioula sob diferentes intervalos de corte. O tratamento mais intenso correspondia a 21 dias entre cortes resultando em digestibilidade de $756 \mathrm{~g} \mathrm{~kg}^{-1}$, superior ao tratamento mais leniente de 49 dias $\left(695 \mathrm{~g} \mathrm{~kg}^{-1}\right)$. Lloveras et al. (1998) também avaliaram o efeito do manejo no valor nutricional da alfafa. A forragem colhida no estádio de início de florescimento apresentou digestibilidade de $738 \mathrm{~g} \mathrm{~kg}^{-1}$, enquanto que a da forragem colhida em florescimento completo foi de $698 \mathrm{~g} \mathrm{~kg}^{-1}$. Sleugh et al. (2000), relataram uma digestibilidade média da Alfagraze de $677,7 \mathrm{~g} \mathrm{~kg}^{-1}$ em regime de corte. Trenblay et al. (2000) avaliaram 27 cultivares de alfafa em estádio de início de florescimento (10\%) obtendo uma digestibilidade média de $668 \mathrm{~g} \mathrm{~kg}^{-1}$. Bélanger et al. (1992) estudaram o efeito de sistemas de corte sob o valor nutritivo da alfafa cv. Apica durante três anos reportando que a influência destes sistemas na digestibilidade da forragem foi variável, com DIVMS entre 546 e $638 \mathrm{~g} \mathrm{~kg}^{-1}$. 
No presente experimento de pastejo os métodos não geraram diferenças de digestibilidade da forragem. Popp et al. (1997) não relataram diferença na digestibilidade da forragem de pastagem consorciada, alfafa/gramínea, entre os métodos de lotação contínua e lotação rotacionada (10 piquetes). A forragem de alfafa sob lotação contínua apresentou digestibilidade média de $582,3 \mathrm{~g} \mathrm{~kg}^{-1}$ e sob lotação rotacionada apresentou 590,6 $\mathrm{g} \mathrm{kg}^{-1}$, onde o material era colhido por um animal fistulado durante 20 minutos de pastejo. Williams e Hammond (1999) também estudaram ambos os métodos, lotação rotacionada e lotação contínua em pastagem de Bahiagrass (Paspalum notatum Flügge). O tratamento de lotação contínua consistia em pastejar a área mantendo a massa de forragem entre 1100 a $1700 \mathrm{~kg} \mathrm{MS} \mathrm{ha}^{-1}$, o que correspondia a uma altura comprimida, utilizando o prato ascendente, de menos de $4 \mathrm{~cm}$. No entanto, os resultados não mostraram diferença de digestibilidade da matéria orgânica, isto devido ao método de coleta do material realizado no início de cada pastejo quando a massa de forragem de ambos os métodos era semelhante. Bertelsen et al. (1993) não encontraram diferença no valor nutritivo da forragem entre os métodos de lotação contínua e lotação intermitente. Porém o método de lotação intermitente aumentou a produção animal por hectare, pois possibilitou maior taxa de lotação sem que houvesse diminuição no desmpenho animal ou do valor nutritivo da forragem, para pastagens consorciadas de alfafa, festuca (Festuca arundinacea Schreb.) e orchadgrass ou dátilo (Dactylis glomerata L.).

Os trabalhos citados anteriormente pesquisaram a forragem consumida juntamente com o desempenho animal, incluindo o fator de seleção e consumo, diferentemente do presente estudo, onde se avaliou a forragem ofertada para caracterizar a resposta da forragem ao pastejo. Devido a isso, a coleta das amostras no campo foi realizada na altura de $7 \mathrm{~cm}$, tanto para o método de pastejo de lotação contínua como para a lotação rotacionada, altura esta adotada como resíduo. Isto influenciou a diferença entre os métodos, pois a lotação contínua sempre apresentava plantas jovens com sete dias de "rebrota" ao contrário das plantas sob lotação rotacionada, que apresentavam 28 ou 42 dias de rebrota. Uma das características do experimento foi a utilização da técnica 
de mob-grazing que não proporciona a seleção do material ofertado pelos animais, resultando em um pastejo uniforme e consequentemente uma rebrota uniforme.

A forragem produzida sob lotação contínua apresentou melhor digestibilidade. $\mathrm{O}$ estande apresentava alta densidade de brotos basais e de baixa estatura, e o material colhido era composto por folhas e hastes jovens. Já sob lotação rotacionada as plantas apresentavam baixa densidade de brotos e alta estatura pré-pastejo, e o material colhido apresentava maior maturidade. O aumento da maturidade influencia no crescimento das hastes e na senescência e abscisão das folhas sombreadas na base da planta e a perda de conteúdo celular (Albrecht et al., 1987; Collins et al., 1980).

Assim como foi possível detectar a influência do método sobre a digestibilidade, a estação do ano também afetou a DIVMS. Vough \& Marten (1971) avaliaram a influência da temperatura e da umidade do solo no valor nutritivo da alfafa sob temperatura mais amena (média diária de $13{ }^{\circ} \mathrm{C}$ ) a digestibilidade foi de $732 \mathrm{~g} \mathrm{~kg}^{-1}$, enquanto que em temperatura mais quente (média diária de $24{ }^{\circ} \mathrm{C}$ ) foi de $697 \mathrm{~g} \mathrm{~kg}^{-1}$. A forragem produzida em solos mais secos apresentaram maior digestibilidade $\left(802 \mathrm{~g} \mathrm{~kg}^{-1}\right)$ que em solos úmidos (758 $\left.\mathrm{g} \mathrm{kg}^{-1}\right)$. O mesmo resultado foi obtido por Smith (1970b) que reportou que alfafas cultivadas em temperaturas amenas $\left(14{ }^{\circ} \mathrm{C}\right)$ apresentaram maiores digestibilidades que em temperaturas quentes $\left(28{ }^{\circ} \mathrm{C}\right)$. A disponibilidade de água e a temperatura mais quente proporcionam maior acúmulo de forragem, influenciando na maturidade da planta (Christian, 1977; Griffin et al., 1994; Kalu \& Fick, 1981, 1983; Smith, 1970a). Isso foi observado nos dados de produção e também teve influência sobre a digestibilidade da alfafa neste trabalho.

As folhas de leguminosas de alta qualidade como a alfafa e o trevo vermelho (Trifolium pratense L.) apresentam mesófilo altamente digestível resultando em digestibilidade dos folíolos de cerca $800 \mathrm{~g} \mathrm{~kg}^{-1}$ (Akin, 1989; Albrecht et al., 1987). Os dados do presente estudo foram ligeiramente inferiores, variando de 752 a $786 \mathrm{~g} \mathrm{~kg}^{-1}$, provavelmente devido à inclusão dos peciólulos nas amostras. Os métodos de pastejo não apresentaram diferença na digestibilidade da forragem devido à baixa variação nos componentes estruturais da folha durante o crescimento da planta (Akin, 1989; Albrecht et al., 1987; Smith, 1970b). Os genótipos estudados apresentaram diferentes valores de 
digestibilidade sob lotação contínua. No verão Alfagraze, Crioula e Pioneer 5432 apresentaram maior digestibilidade diferentemente do inverno, onde os genótipos CUF 101, ABT 805 e Pioneer 5432 produziram forragem mais digestível in vitro. Essa diferença entre genótipos pode não ser consistente entre anos e cortes, indicando o efeito determinante do meio ambiente na rebrota e consequentemente no valor nutritivo da forragem (Griffin et al., 1994).

As hastes possuem um impacto maior na qualidade da forragem do que as folhas devido à alta concentração de fibra na hate (Onstad \& Fick, 1983; Sheaffer et al., 2000). Buxton et al. (1987) avaliaram o valor nutritivo das hastes em diferentes genótipos de alfafa. Onde os cultivares comerciais apresentaram digestibilidade média de 338,8 g $\mathrm{kg}^{-1}$. Buxton \& Hornstein (1986) reportaram que a porção de parede celular representa cerca de $200 \mathrm{~g} \mathrm{~kg}^{-1}$ nas folhas e $700 \mathrm{~g} \mathrm{~kg}^{-1}$ nas hastes de alfafa. Porém Albrecht et al. (1987), estudaram o valor nutritivo de hastes e folhas de alfafa de acordo com o estádio de desenvolvimento iniciando no estádio vegetativo até início de formação de sementes. Neste estudo houve queda da digestibilidade de hastes de 750 a $480 \mathrm{~g} \mathrm{~kg}^{-1}$ em condições de seca e uma queda de 760 a $535 \mathrm{~g} \mathrm{~kg}^{-1}$ nas chuvas, conforme aumento a maturidade da planta. O presente trabalho apresentou dados de digestibilidade semelhantes ao reportado por Albrecht et al. (1987) isto provavelmente devido ao método de pastejo adotado e à altura de resíduo de $7 \mathrm{~cm}$, não permitindo a colheita de material morto e a base da haste. Segundo Buxton et al (1987) quanto mais próximo da coroa maior é a concentração de parede celular por ser esta uma região onde predominam o tecidos mais maduros.

\subsubsection{Teores de proteína bruta}

As amostras de planta inteira e de haste seguiram o mesmo padrão, quanto ao teor de PB. Sob lotação contínua o teor de PB foi maior do que sob lotação rotacionada (Tabela 12 e Tabela 15). Na fração a folha os genótipos apresentaram concentrações semelhantes (Tabela 14). 
Para o teor de PB na planta inteira houve efeito de método de pastejo $(P=0,0533)$, estação do ano $(P=0,0538)$, e da interação método $\times$ estação $(P=0,0022)$.

Tabela 12. Teor de proteína bruta (PB) na planta inteira nos métodos de pastejo e das estações.

\begin{tabular}{|c|c|c|c|}
\hline Método de pastejo & Verão & Inverno & EPM \\
\hline & 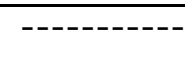 & $--\mathrm{g} \mathrm{kg}^{-1}---$ & (------ \\
\hline Lotação contínua & $358,76^{\mathrm{Aa}}$ & $340,99^{\mathrm{Ab}}$ & 6,861 \\
\hline Lotação rotacionada & $236,52^{\mathrm{Ba}}$ & $241,91^{\mathrm{Ba}}$ & 6,861 \\
\hline
\end{tabular}

Os teores de PB da fração folha apresentaram diferença quanto ao método de pastejo $(P=0,0547)$, além do efeito da interação método $\times$ genótipo $\times$ estação $(P=0,0241)$.

Tabela 13. Valores de $P$ para efeito da estação em cada combinação genótipo $\times$ método e de método em cada combinação genótipo $\times$ estação, para teor de PB nas folhas.

\begin{tabular}{|c|c|c|c|c|}
\hline \multirow{3}{*}{ Genótipo } & \multirow{2}{*}{\multicolumn{2}{|c|}{$\begin{array}{c}\text { Efeito de Estação dentro de } \\
\text { Método }\end{array}$}} & \multirow{2}{*}{\multicolumn{2}{|c|}{$\begin{array}{c}\text { Efeito de Método dentro de } \\
\text { Estação }\end{array}$}} \\
\hline & & & & \\
\hline & Contínuo & Rotacionado & Verão & Inverno \\
\hline & \multicolumn{4}{|c|}{------------------------ $\quad$ valores $\operatorname{de} P$-------------------- } \\
\hline ABT 805 & 0,27 n.s & $0,41 \mathrm{n} . \mathrm{s}$ & $0,01 *$ & $0,01 *$ \\
\hline Alfagraze & $0,56 \mathrm{n} . \mathrm{s}$ & 0,95 n.s & $0,08 *$ & $0,01 *$ \\
\hline Crioula & $0,09 *$ & $0,01 *$ & 0,97 n.s & $0,01 *$ \\
\hline CUF 101 & $0,09 *$ & 0,30 n.s & $0,01 *$ & 0,23 n.s \\
\hline Pioneer 5432 & $0,05 *$ & 0,90 n.s & $0,01 *$ & $0,06 *$ \\
\hline
\end{tabular}


Tabela 14. Teor de proteína bruta $(\mathrm{PB})$ da folha de alfafa sob pastejo no verão e no inverno.

\begin{tabular}{|c|c|c|c|c|}
\hline \multirow[t]{2}{*}{ Genótipo } & \multicolumn{2}{|c|}{ Lotação contínua } & \multicolumn{2}{|c|}{ Lotação rotacionada } \\
\hline & Verão & Inverno & Verão & Inverno \\
\hline & $\cdots$ & . & & ------- \\
\hline ABT 805 & $393,3^{a}$ & $376,0^{a b}$ & $343,2^{b}$ & $330,6^{a}$ \\
\hline Alfagraze & $367,0^{\mathrm{a}}$ & $377,4^{\mathrm{ab}}$ & $336,1^{b}$ & $335,3^{a}$ \\
\hline Crioula & $369,6^{\mathrm{a}}$ & $404,2^{\mathrm{a}}$ & $369,1^{\mathrm{a}}$ & $315,0^{\mathrm{a}}$ \\
\hline CUF 101 & $393,5^{a}$ & $360,1^{b}$ & $324,1^{b}$ & $340,3^{a}$ \\
\hline Pioneer 5432 & $395,3^{a}$ & $361,5^{b}$ & $332,4^{b}$ & $334,2^{\mathrm{a}}$ \\
\hline
\end{tabular}

${ }^{\mathrm{ab}}$ Médias na coluna seguidas de mesmas letras minúsculas não diferem entre si $(\mathrm{P}>0,10)$.

Houve efeito de método de pastejo $(P=0,0265)$ e da interação método $\times$ estação $(P=0,0001)$ sobre o teor de $\mathrm{PB}$ nas hastes, mas nem a estação $(P=0,1139)$ nem a interação método $\times$ genótipo $(P=0,1079)$ influenciaram essa resposta.

No desdobramento da interação método $\times$ genótipo não se detectou diferença nos teores de PB nas hastes de alfafa sob lotação rotacionada. Sob lotação contínua houve diferença $(P=0,0917)$ entre os genótipos, com Crioula $\left(253,75 \mathrm{~g} \mathrm{~kg}^{-1}\right)$ e CUF 101 (248,37 $\left.\mathrm{g} \mathrm{kg}^{-1}\right)$ os melhores, Pioneer $5432\left(232,05 \mathrm{~g} \mathrm{~kg}^{-1}\right)$ intermediário e ABT 805 $\left(228,32 \mathrm{~g} \mathrm{~kg}^{-1}\right)$ e Alfagraze $\left(225,45 \mathrm{~g} \mathrm{~kg}^{-1}\right)$ os inferiores. Também houve efeito da interação método × estação está descrito na Tabela 15 .

Tabela 15. Teor de proteína bruta $(\mathrm{PB})$ na fração haste mo métodos de pastejo no verão e no inverno.

\begin{tabular}{|c|c|c|c|}
\hline Método de pastejo & Verão & Inverno & EPM \\
\hline & \multicolumn{3}{|c|}{------------------------- g kg $^{-1}---------------------$} \\
\hline Lotação contínua & $223,30^{\mathrm{Ab}}$ & $251,88^{\text {Аа }}$ & 4,095 \\
\hline Lotação rotacionada & $133,40^{\mathrm{Ba}}$ & $116,63^{\mathrm{Bb}}$ & 4,095 \\
\hline
\end{tabular}

AB Médias na coluna seguidas de mesmas letras maiúsculas não diferem entre si $(\mathrm{P}>0,10)$.

${ }^{\mathrm{ab}}$ Médias na linha seguidas de mesmas letras minúsculas não diferem entre si $(\mathrm{P}>0,10)$. 
O método de pastejo afetou o teor de PB na forragem da mesma forma que afetou a digestibilidade, confirmando o reportado na literatura, que têm mostrado que o valor nutritivo da alfafa decresce com o aumento na maturidade (Buscaglia et al., 1994; Monteiro et al., 1998). Segundo Botrel et al. (1996), o teor de proteína da alfafa Crioula seguiu a mesma tendência da digestibilidade com valores variando de $304 \mathrm{~g} \mathrm{~kg}^{-1}$ a $247 \mathrm{~g}$ $\mathrm{kg}^{-1}$, para 21 e 49 dias de intervalo de cortes, respectivamente. Sleugh et al. (2000) avaliaram o valor nutritivo da forragem em pastagens consorciadas e de estandes puros de alfafa. A Alfagraze foi colhida no início de florescimento (10\%) com um teor médio de PB de 195,1 $\mathrm{g} \mathrm{kg}^{-1}$ durante dois anos. Resultado semelhante foi obtido por Lloveras et al. (1998) que avaliaram dois cultivares de alfafa sob corte de acordo com o estádio morfológico. Alfafa colhida no início de florescimento apresentou teor de $212 \mathrm{~g} \mathrm{~kg}^{-1} \mathrm{e}$ em florescimento completo apresentou $196 \mathrm{~g} \mathrm{~kg}^{-1}$ (média dos dois cortes).

Herling et al. (1998) realizaram avaliações de valor nutritivo da alfafa Crioula sob cortes de acordo com o estádio de florescimento (10, 50 e $100 \%$ de florescimento). No primeiro corte, o aumento da maturidade causou uma diminuição no teor de PB de 272,6 $\mathrm{g} \mathrm{kg}^{-1}$ para $114,1 \mathrm{~g} \mathrm{~kg}^{-1}$, para 10 e $100 \%$ de florescimento respectivamente. Já no segundo corte a forragem com $10 \%$ de florescimento $\left(304,9 \mathrm{~g} \mathrm{~kg}^{-1}\right)$ apresentou teores superiores ao de $100 \%$ (286 $\left.\mathrm{g} \mathrm{kg}^{-1}\right)$. Nordkvist \& Åman (1986) reportaram a queda do teor de proteína com o aumento da produção da alfafa cultivar Vertus. Um aumento de 800 para $9500 \mathrm{~kg} \mathrm{ha}^{-1}$ correspondeu a um decréscimo de 368 para $129 \mathrm{~g} \mathrm{~kg}^{-1}$ no teor de PB. Apesar da grande variação dos teores de PB encontrado na maioria da literatura citada, é possível encontrar valores semelhantes ao obtido neste trabalho para forragem no mesmo estádio de desenvolvimento.

A variação de teor de PB entre os genótipos estudado no presente trabalho não foi significativa, diferentemente dos trabalhos reportados na literatura. Kallenbach et al., 2000 avaliaram dois genótipos "tipo feno" (Pioneer 5373 e Cody) e um "tipo pastejo" (Alfagraze). A Alfagraze (229 $\mathrm{g} \mathrm{kg}^{-1}$ ) apresentou concentração média maior que a de Pioneer 5373 (222,7 $\left.\mathrm{g} \mathrm{kg}^{-1}\right)$ e de Cody (219,7 $\left.\mathrm{g} \mathrm{kg}^{-1}\right)$, em cortes com intervalo de 42 a 28 dias de descanso. Monteiro et al. (1998) estudaram o valor nutritivo de 27 cultivares de alfafa no estado do Paraná, e encontraram diferença nos teores de PB. A forragem era 
colhida com 10 a $20 \%$ de florescimento, e dos cultivares avaliados, Crioula (198,5 g $\left.\mathrm{kg}^{-1}\right)$ e CUF $101\left(194,7 \mathrm{~g} \mathrm{~kg}^{-1}\right)$ apresentaram os menores teores de PB e C/W 8746 $\left(221,9 \mathrm{~g} \mathrm{~kg}^{-1}\right)$ apresentou o maior de teor.

A diferença de concentração de proteína entre genótipos pode ser atribuída a ciclos de desenvolvimento e condições ambientais diversas, os genótipos que têm menores teores de proteína bruta apresentando taxas de acúmulo de forragem maiores mais rápidas (Oliveira, 1986). Segundo Brummer \& Bouton, (1992), a tolerância ao pastejo pode estar relacionada com a habilidade da alfafa em manter uma área foliar mínima na região abaixo da altura de resíduo. Isso favorece a rebrota mais rápida pois as folhas localizadas na parte baixa do relvado readquirem a sua atividade fotossintética tornado-a independente das reservas da raiz. Apesar dos genótipos utilizados no presente trabalho apresentarem diferentes aptidões, não foi evidenciada a superioridade de nenhum deles em particular. $\mathrm{O}$ teor de PB na forragem foi o resultado de boa adaptação dos genótipos importados ao local e ao tratamento imposto.

Comparando as estações do ano, a forragem sob lotação contínua apresentou maior teor de PB no verão (358,7 $\mathrm{g} \mathrm{kg}^{-1}$ ) que no inverno (340,9 $\left.\mathrm{g} \mathrm{kg}^{-1}\right)$, o que não ocorreu na lotação rotacionada onde ambas as estações apresentaram o mesmo teor de PB (239 $\mathrm{g} \mathrm{kg}^{-1}$ ). De acordo com a literatura onde, normalmente, a concentração de proteína no inverno é maior do que no verão devido à menor taxa de acúmulo de forragem (Buscaglia et al., 1994; Monteiro et al., 1998). No presente trabalho TMDAV foi superior à TMDAI para ambos os métodos de pastejo. Durante o experimento a temperatura média do verão foi de $23,7{ }^{\circ} \mathrm{C}$ e no inverno $20,1{ }^{\circ} \mathrm{C}$ e Smith (1970) observou que a alfafa apresenta maior teor de PB em temperaturas ao redor de 21 a $27{ }^{\circ} \mathrm{C}$, o que explica ao menos parcialmente a diferença mínima entre as estações. Portanto, apesar da maior taxa de acúmulo de forragem, o verão de 2001 apresentou temperatura favorável à alta concentração de $\mathrm{PB}$ na forragem.

O teor de PB nas folhas foi diferente entre os genótipos, métodos e estações. Sheaffer et al. (2000) avaliaram o valor nutritivo de seis genótipos de alfafa em três diferentes cidades em Minnesota, EUA. Foram impostos dois regimes de corte onde a forragem era colhida no início e no final do florescimento, resultando em diferentes 
teores de PB nas folhas que variaram de 284 a $304 \mathrm{~g} \mathrm{~kg}^{-1}$ para a forragem colhida no início e 264 a $278 \mathrm{~g} \mathrm{~kg}^{-1}$ colhidas no final do florescimento. Herling et al. (1998) relataram um padrão semelhante no teor de $\mathrm{PB}$ nas folhas de Crioula em dois cortes, que variaram de 344,5 a 423,4 $\mathrm{g} \mathrm{kg}^{-1}$ para forragem cortadas com $10 \%$ de florescimento e 329,5 a $335,7 \mathrm{~g} \mathrm{~kg}^{-1}$ para $100 \%$ de florescimento. O mesmo ocorreu no presente trabalho quando se comparam os métodos de pastejo. As folhas da forragem sob lotação contínua apresentaram maiores teores de PB que sob lotação rotacionada.

Os genótipos apresentaram diferentes teores de PB nas folhas, porém Crioula mostrou-se superior. Esta característica deve estar relacionada ao fator genético. As folhas apresentam altos teores de proteína devido à alta concentração da Rubisco (Ribulose-1,5-bifosfato carboxilase), enzima fotossintética, que chega a ser $50 \%$ da proteína solúvel nas folhas (Nussio \& Manzano, 1999; Wilson, 1994). A alteração na quantidade de proteínas nas folhas só seria possível através da alteração do sistema metabólico ou da genética da planta. Contudo, a diferença dos teores de PB entre os genótipos poderia ser explicada pela quantidade de folhas fotossintéticamente ativas, que é determinada genéticamente e pela idade, apesar da baixa variação do valor nutritivo da folha conforme a maturidade da planta (Albrecht et al. 1987; Herling et al., 1998; Sheaffer et al. 2000). Segundo Christian (1977) o crescimento da folha de alfafa até a sua expansão completa acarreta em um aumento da área, peso e atividade fotossintética, sendo que a taxa de desenvolvimento, isto é o número de dias para a expansão completa da folha, está relacionada com a taxa de aparecimento de folhas e hastes.

As hastes apresentaram diferença entre os métodos assim como a planta inteira. Sheaffer et al. (2000) reportaram teores variando de 115 a $114 \mathrm{~g} \mathrm{~kg}^{-1}$ para forragem cortada no início do florescimento e 96 a $102 \mathrm{~g} \mathrm{~kg}^{-1}$ para o final do florescimento. Os teores obtidos no presente trabalho foram superiores ao relatado na literatura, principalmente sob lotação contínua, devido à característica da colheita da haste.

Comparando as estações observa-se que a haste apresentou maior teor de PB durante o verão em comparação ao inverno sob lotação rotacionada. Já para a lotação contínua ocorreu o oposto, onde o inverno proporcionou teores superiores que o verão. $\mathrm{O}$ esperado seria maiores teores de PB no inverno do que no verão devido ao acúmulo 
de forragem ser maior no verão e com isso as plantas seriam colhidas com um grau de maturidade maior (Monteiro et al. 1998). Sob lotação rotacionada a forragem de verão apresentou maiores teores de $\mathrm{PB}$ provavelmente devido ao intervalo entre pastejos ter sido de 28 dias, proporcionando a colheita de material mais jovem que coletado durante o inverno (42 dias). Já sob lotação contínua o intervalo entre as amostragens foi de sete dias resultando na colheita de hastes mais desenvolvidas no verão que no inverno, afetando assim o teor de PB.

O valor nutritivo da forragem sofre variação durante o decorrer do dia, resultando no seu aumento ao final da tarde, devido ao acúmulo de fotoassimilados na forragem, resulta na diluição da fração parede celular (Buxton \& Fales, 1994). No presente experimento, a amostragem da forragem para determinação de valor nutritivo foi demorada sendo realizada, normalmente, durante um dia inteiro e quando necessário no dia seguinte. A coleta foi realizada por blocos buscando minimizar o erro dentro de blocos.

\subsubsection{Teores de FDN, FDA e lignina}

Houve diferença no teor de fibra em detergente neutro (FDN) da planta inteira entre as estações $(P=0,0001)$ além do efeito da interação método $\times$ estação $(P=0,0001)$. No desdobramento da interação entre método $\times$ estação não se detectou diferença nos teores de FDN na forragem sob lotação contínua. Sob lotação rotacionada houve diferença entre o verão $(P=0,0002)$ e inverno $(P=0,0023)$ (Tabela 16).

Tabela 16. Teor de FDN na planta inteira nos métodos de pastejo no verão e no inverno.

\begin{tabular}{llcc}
\hline Método de pastejo & Verão & Inverno & EPM \\
\hline & --- Lotação contínua $^{243,67^{\mathrm{Ba}}}$ & $238,30^{\mathrm{Ba}}$ & 1,2185 \\
Lotação rotacionada & $342,63^{\mathrm{Aa}}$ & $308,43^{\mathrm{Ab}}$ & 1,2185
\end{tabular}

Médias na coluna seguidas de mesmas letras maiúsculas não diferem entre si $(\mathrm{P}>0,10)$

${ }^{\mathrm{ab}}$ Médias na linha seguidas de mesmas letras minúsculas não diferem entre si $(\mathrm{P}>0,10)$. 
O teor de FDN na folha não diferiu entre os métodos $(P=0,8764)$, entre os genótipos $(P=0,4714)$, ou estações $(P=0,8643)$ além do que não houveram quaisquer interações entre as causas de variação. A concentração média de FDN da folha foi $225 \mathrm{~g}$ $\mathrm{kg}^{-1}$.

$O$ teor de FDN na fração haste diferiu entre métodos de pastejo $(P=0,0382)$, estações $(P=0,0001)$ e houve efeito da interação método $\times$ estação $(P=0,0001)$. $\mathrm{O}$ desdobramento da interação método $\times$ estação mostrou diferença entre estações para o método de lotação contínua $(P=0,0001)$, e efeito do método de pastejo tanto no verão $(P=0,0001)$ como no inverno $(P=0,0001)$ (Tabela 17).

Tabela 17. Teor de FDN na haste de alfafa nos métodos de pastejo e nas estações.

\begin{tabular}{|c|c|c|c|}
\hline Método de pastejo & Verão & Inverno & EPM \\
\hline & \multicolumn{3}{|c|}{-------------------------g kg } \\
\hline Lotação contínua & $432,11^{\mathrm{Ba}}$ & $356,31^{\mathrm{Bb}}$ & 6,000 \\
\hline Lotação rotacionada & 516,17 Aa & 520,94 Aa & 6,000 \\
\hline
\end{tabular}

$\mathrm{O}$ teor de FDN na planta inteira aumentou com o avanço na maturidade, $\mathrm{o}$ mesmo acontecendo com as hastes. Não se observa, porém, o mesmo padrão para as folhas. A diferença no teor de FDN entre as estações foi detectada para a planta inteira sob lotação rotacionada, com o inverno apresentando valor superior ao verão, o mesmo acontece com a haste para a lotação contínua.

O teor de FDA na planta inteira diferiu entre os métodos $(P=0,0331)$ e entre as estações $(P=0,0001)$ de maneira similar ao FDN. O método de lotação rotacionada resultou em forragem com teor de FDA mais alto $\left(255,1 \mathrm{~g} \mathrm{~kg}^{-1}\right)$ do que sob lotação contínua $\left(182,2 \mathrm{~g} \mathrm{~kg}^{-1}\right)$ e forragem de verão $\left(235,8 \mathrm{~g} \mathrm{~kg}^{-1}\right)$ com teor maior que a de inverno $\left(201,5 \mathrm{~g} \mathrm{~kg}^{-1}\right)$.

O teor de FDA na folha sofreu efeito de estação $(P=0,0005)$ além das interações método $\times$ genótipo $(P=0,0406)$ e estação $\times$ genótipo $(P=0,0619)$. A variação no teor 
absoluto de FDA na folha foi mínima, porém as diferenças genéticas entre os materiais testados ficaram evidenciadas dentro de cada método de pastejo.

Tabela 18. Teor de FDA na folha de alfafa em resposta ao método de pastejo.

\begin{tabular}{|c|c|c|}
\hline Genótipo & Lotação contínua & Lotação rotacionada \\
\hline & \multicolumn{2}{|c|}{ 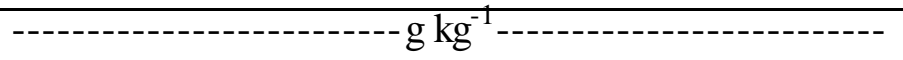 } \\
\hline ABT 805 & $156,12^{b}$ & $162,30^{\mathrm{bc}}$ \\
\hline Alfagraze & $158,51^{\mathrm{ab}}$ & $159,32^{c}$ \\
\hline Crioula & $147,85^{\mathrm{b}}$ & $171,00^{\mathrm{a}}$ \\
\hline CUF 101 & $162,98^{\mathrm{a}}$ & $165,17^{\mathrm{b}}$ \\
\hline Pioneer 5432 & $158,60^{a b}$ & $163,45^{b}$ \\
\hline
\end{tabular}

Tabela 19. Teor de FDA na folha de alfafa sob pastejo no verão e no inverno.

\begin{tabular}{|c|c|c|}
\hline Genótipo & Verão & Inverno \\
\hline & --1-- & 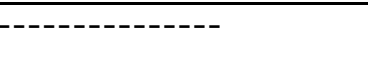 \\
\hline ABT 805 & $174,55^{\mathrm{ns}}$ & $143,87^{\mathrm{b}}$ \\
\hline Alfagraze & $169,64^{\mathrm{ns}}$ & $148,20^{b}$ \\
\hline Crioula & $163,10^{\mathrm{ns}}$ & $155,74^{\mathrm{a}}$ \\
\hline CUF 101 & $165,15^{\mathrm{ns}}$ & $163,00^{\mathrm{a}}$ \\
\hline Pioneer 5432 & $175,00^{\mathrm{ns}}$ & $147,05^{b}$ \\
\hline \multicolumn{3}{|c|}{$\begin{array}{l}\text { EPM }=4,607 \\
\text { ab Médias na coluna seguidas de mesmas letras minúsculas não diferem entre si }(\mathrm{P}>0,10) \text {. } \\
\text { ns Médias na coluna não apresentaram diferença significativa }(\mathrm{P}>0,10) \text {. }\end{array}$} \\
\hline \multicolumn{3}{|c|}{$\begin{array}{l}\text { A haste, diferentemente da folha, apresentou diferença marcante com relação à } \\
\text { fibra, entre os métodos de pastejo e entre as estações do ano. Sob lotação rotacionada a } \\
\text { forragem apresentou teor de FDA superior àquele sob lotação contínua tanto no verão } \\
\text { como no inverno. A diferença entre as estações só existiu sob lotação contínua e este } \\
\text { mesmo padrão é observado para o teor de FDN. Isto provavelmente ocorreu devido à }\end{array}$} \\
\hline
\end{tabular}


maior taxa de acúmulo aliado com a frequência de pastejo tornando mais suscetível à variação da concentração de fibras.

Tabela 20. Teor de FDA na haste de alfafa sob pastejo no verão e no inverno.

\begin{tabular}{|c|c|c|c|}
\hline Método de pastejo & Verão & Inverno & EPM \\
\hline & \multicolumn{3}{|c|}{----------------------- g kg $^{-1}$} \\
\hline Lotação contínua & $367,81^{\mathrm{Ba}}$ & $287,98^{\mathrm{Bb}}$ & 4,724 \\
\hline Lotação rotacionada & $458,16^{\mathrm{Aa}}$ & $455,90^{\mathrm{Aa}}$ & 4,724 \\
\hline
\end{tabular}

A concentração de lignina na planta inteira foi diferente entre métodos $(\mathrm{P}=0,0387)$ e estações $(P=0,0002)$. A forragem sob lotação contínua apresentou menor teor de lignina $\left(35 \mathrm{~g} \mathrm{~kg}^{-1}\right)$ do que sob lotação rotacionada $\left(50,6 \mathrm{~g} \mathrm{~kg}^{-1}\right)$ e a forragem produzida no verão apresentou mais lignina (45,3 $\left.\mathrm{g} \mathrm{kg}^{-1}\right)$ que no inverno $\left(40,3 \mathrm{~g} \mathrm{~kg}^{-1}\right)$.

A diferença entre as concentrações de lignina foi melhor observada nas folhas dos genótipos de alfafa, tendo sido registrado efeito de estações $(P=0,0002)$ além das interações método $\times$ genótipo $(P=0,0553)$, método $\times$ estação $(P=0,0757)$, estação $\times$ genótipo $(P=0,0119)$ e metodo $\times$ estação $\times$ cultivar $(P=0,0874)$.

Tabela 21. Teor de lignina na folha de alfafa sob pastejo no verão e no inverno.

\begin{tabular}{|c|c|c|c|c|}
\hline \multirow[t]{2}{*}{ Genótipo } & \multicolumn{2}{|c|}{ Lotação contínua } & \multicolumn{2}{|c|}{ Lotação rotacionada } \\
\hline & Verão & Inverno & Verão & Inverno \\
\hline & $-\cdots$ & - & $-\cdots$ & - \\
\hline ABT 805 & $33,3^{a}$ & $26,3^{\mathrm{c}}$ & $36,6^{\mathrm{a}}$ & $31,2^{\mathrm{b}}$ \\
\hline Alfagraze & $32,2^{\mathrm{a}}$ & $32,6^{\mathrm{a}}$ & $36,5^{\mathrm{a}}$ & $30,5^{b}$ \\
\hline Crioula & $30,8^{a}$ & $29,9^{\mathrm{ab}}$ & $36,6^{\mathrm{a}}$ & $34,3^{a}$ \\
\hline CUF 101 & $31,9^{\mathrm{a}}$ & $31,7^{\mathrm{a}}$ & $34,1^{\mathrm{b}}$ & $35,0^{\mathrm{a}}$ \\
\hline Pioneer 5432 & $34,0^{\mathrm{a}}$ & $31,2^{\mathrm{a}}$ & $37,5^{\mathrm{a}}$ & $31,0^{b}$ \\
\hline
\end{tabular}


Os teores de lignina na haste foram afetados por método $(P=0,0384)$, estação $(P=0,0001)$ e pela a interação entre método $\times$ estação $(P=0,0001)$.

Tabela 22. Teor de lignina da haste de alfafa sob pastejo no verão e no inverno.

\begin{tabular}{|c|c|c|c|}
\hline Método de pastejo & Verão & Inverno & EPM \\
\hline & & $--\mathrm{g} \mathrm{kg}^{-1}$ & \\
\hline Lotação contínua & $66,8^{\mathrm{Ba}}$ & $48,1^{\mathrm{Bb}}$ & 1,399 \\
\hline Lotação rotacionada & $85,2^{\mathrm{Aa}}$ & $86,3^{\mathrm{Aa}}$ & 1,399 \\
\hline
\end{tabular}

O método de pastejo, assim como ocorreu para a concentração de $\mathrm{PB}$, afetou a concentração de fibra. Sob lotação contínua a forragem apresentou teores de fibra em geral inferiores aos daquela produzida sob lotação rotacionada, o que está provavelmente associado com o tempo de rebrota e com a maturidade da forragem colhida. O efeito da maturidade é primeiramente relacionado com a mudança na concentração na composição do tecido da haste, já que o tecido da folha sofre pouca variação (Kalu \& Fick, 1983; Fick \& Onstand, 1988; Griffin et al. 1994).

A parede celular das plantas é constituída em grande parte por polissacarídeos e em menor parte por lignina e proteína. Durante o crescimento e a maturação da forragem, a parede celular apresenta maior espessamento e lignificação, principalmente em células associadas com o suporte e o transporte de água (Albrecht et al. 1987). Não só na planta como um todo, mas também na haste madura é provável notar diferentes concentrações de FDA, FDN, celulose e hemicelulose. A base da haste, localizada perto da coroa, apresenta maiores concentrações de fibra que o topo, refletindo maior maturidade (Iwaasa et al. 1996). O diâmetro da haste tende a aumentar conforme a planta de alfafa cresce e com isso a necessidade de tecido de suporte aumenta, aumentando a proporção de células com paredes mais espessas e lignificadas (Iwaasa et al. 1996; Jung \& Engels, 2002). 
O tecido foliar deve ter sofrido menor influência da maturidade da planta na sua composição. Albrecht et al. (1987) reportaram o mesmo em dois anos de experimento. A composição bromatológica da folha.

Segundo Griffin et al. (1994) o efeito da maturidade sobre a composição da forragem é diferente nas estações do ano. Van Soest (1982) observou que a mudança na temperatura durante as estações faz com que a concentração de lignina e de parede celular na haste da alfafa aumente. Isto ocorre devido ao estímulo ao crescimento, aumentando o acúmulo de forragem, como foi observado no presente trabalho, acarretando assim em maiores concentrações de FDN, FDA e lignina. O mesmo efeito ocorre em menor extensão nos tecidos da folha (Albrecht et al., 1987; Kalu \& Fick, 1983). A influência da temperatura sobre o teor de FDA de plantas que não estão em estresse hídrico é mínimo (Vough \& Marten, 1971). Os dados do presente experimento seguiram o padrão descrito pela literatura, com a forragem produzida no verão apresentando maiores teores de lignina que a forragem produzida no inverno.

As concentrações dos componentes da fibra obtidas neste experimento equiparam-se àquelas obtidas Sheaffer et al. (1998 e 2000). Os valores médios de FDN foram de 410, 215 e $632 \mathrm{~g} \mathrm{~kg}^{-1}$ para planta inteira, folha e haste, respectivamente e seguindo a mesma ordem os valores médios de FDA foram de 365, 178 e $536 \mathrm{~g} \mathrm{~kg}^{-1}$. Kalu \& Fick (1983) observaram valores de FDN entre 200 a $300 \mathrm{~g} \mathrm{~kg}^{-1}$, FDA entre $130 \mathrm{a}$ $220 \mathrm{~g} \mathrm{~kg}^{-1}$ e lignina entre 30 a $60 \mathrm{~g} \mathrm{~kg}^{-1}$, com uma baixa variação nas folhas com o avanço da maturidade. As hastes apresentaram aumento na concentração de fibra com o avanço da maturidade.

A importância da concentração de fibra nos alimentos volumosos está relacionada com a sua utilização na formulação de dietas animais. Harlan et al. (1990) concluíram que a FDA foi melhor que a FDN para predizer o desempenho de vacas leiteiras (Bos taurus) em lactação, mas Turnbull et al. (1982) argumentaram que alimentando vacas leiteiras com feno de alta qualidade baseado no teor de FDA resultam em leite com baixa percentagem de gordura. A alta correlação encontrada por Sheaffer et al. (1998) entre FDN e FDA e a qualidade do leite produzido, sugere que ambas as 
frações são bons indicadores de qualidade e quantidade de teor de fibra da alfafa não havendo a necessidade e se utilizar os dois indicadores na formulação de rações. 


\section{CONCLUSÃO}

As limitações encontradas para a utilização de alfafa sob pastejo podem ser controladas com medidas relacionadas com um manejo adequado. O presente trabalho teve a iniciativa de avaliar diferentes genótipos de alfafa nas condições do Brasil Central através de dois diferentes métodos de pastejo. Os dados gerados mostraram que ambos os métodos mostraram grande influencia tanto na produção como no valor nutritivo, assim como a boa adaptação dos genótipos nas condições impostas.

O método de lotação contínua apresenta maior produção tanto no verão quanto no inverno, sendo que os genótipos ABT 805, Alfagraze e Pioneer 5432, com produção média de 25,7 $\mathrm{Mg} \mathrm{ha}^{-1}$, apresentam maior acúmulo de forragem que Crioula e CUF 101, com 19,6 $\mathrm{Mg} \mathrm{ha}^{-1}$. Aliado à alta produtividade, o método também proporciona a produção de forragem com teor de PB e DIVMS superiores e teores de FDN, FDA e lignina inferiores àquelas produzidas sob lotação rotacionada.

Os genótipos apresentam valores nutritivos semelhantes apesar da diferença na taxa de acúmulo de forragem e no acúmulo total de forragem. Sendo assim podemos concluir que os genótipos tolerantes ao pastejo, ABT 805, Alfagraze e Pioneer 5432, apresentam maiores vantagens na sua utilização em sistemas de produção animal a pasto sob lotação contínua. Sistemas que utilizam método de lotação rotacionada podem utilizar os genótipos não-tolerantes, Crioula e CUF, pois estes apresentam melhor produção e o valor nutritivo semelhante aos genótipos tolerantes. 


\section{REFERÊNCIAS BIBLIOGRÁFICAS}

AGUIAR, A. P. A. Pastagem para gado leiteiro. In: SIMPÓSIO SOBRE PRODUÇÃO DE LEITE NO BRASI, 1., Viçosa, 1999. Desafios tecnológicos para produção de leite no Brasil: Anais. Viçosa: UFV, 1999. p. 43-116.

AKIN, D.E. Histological and physical factors affecting digestibility of forages. Agronomy Journal, v. 81, p. 17-25, 1989.

ALBRECHT, K.A.; WEDIN, W.F.; BUXTON, D.R. Cell-wall composition and digestibility of alfalfa stems and leaves. Crop Science, v. 27, p. 735-741, 1987.

ALLEN, V.G; WOLF, D.D.; FONTENOT, J.P; CARDINA, J.; NOTTER, D.R. Yield and regrowth characteristics of alfalfa grazed with sheep. I. Spring grazing. Agronomy Journal, v. 78, p. 974-979, 1986.

ALVIM, M. J.; BOTREL, M. A. Época de plantio de alfafa (Medicago sativa L.), na zona da mata de Minas Gerais. Revista da Sociedade Brasileira de Zootecnia, v. 24, n. 4, p. 510-521, 1995.

BAILEY, A.T.; ERDMAN, R.A.; SMITH, L.W.; SHARMA, B.K. Particle size reduction during initial mastication of forages by dairy cattle. Journal of Animal Science, v. 68, p. 2084-2094, 1990. 
BALSALOBRE, M. A. A.; SANTOS, P. M.; BARROS, A. L. M. Inovações tecnológicas, investimentos financeiros e gestão de sistema de produção animal em pastagens.. In: SIMPÓSIO SOBRE MANEJO DE PASTAGENS, 19., Piracicaba, 2002. Anais. Piracicaba: FEALQ, 2002. p. 1-30.

BARNES, D. K.; SHEAFFER, C. C. Alfalfa. In: HEATH, M.; METCALFE, D.; BARNES, R. (Ed.). Forages. 5. ed. Ames: Iowa State University, 1995. v. 1, p. 205-216.

BASIGALUP, D. H. Present and future of alfalfa as a grazing crop in south America. In: NORTH AMERICAN ALFALFA IMPROVEMENT CONFERENCE., 37., Madison, 2000. Proceedings. http://www.naaic.org (11 dec. 2002).

BATES, G.W.; HOVELAND, C.S.; McCANN, M.A.; BOUTON, J.H.; HILL, N.S. Plant persistence and animal performance for continuously stocked alfalfa pastures ate three forage allowances. Journal of Production and Agriculture, v. 9, p. 418-423, 1996.

BÉLANGER, G.; RICHARDS, J.E.; McQUEEN, R.E. Effects of harvesting systems on yield, persistence, and nutritive value of alfalfa. Canadian Journal of Plant Science, v. 72, p. 793-799, 1992.

BELESKY, D.P.; FEDDERS, J.M. Residue height influences stand dynamics of alfalfa grown on a shallow soil. Agronomy Journal, v. 89, p. 975-980, 1997.

BERTELSEN, B.S.; FAULKNER, D.B.; BUSKIRK, D.D.; CASTREE, J.W. Beff cattle performance and forage characteristics of continuous, 6-paddock, and 11-paddock grazing systems. Journal of Animal Science, v. 73, p. 1381-1389, 1993. 
BITTMAN, S.; McCARTNEY, D. H. Evaluating alfalfa cultivars and germoplasms for pastures using the mob grazing technique. Canadian Journal of Plant Science, v. 74, p. 109-114, 1994.

BOTREL, M.A.; ALVIM, M.J.; XAVIER, D.F. Frequencia de corte de alfafa (Medicago sativa L.) cv. Crioula em Minas Gerais. Revista da Sociedade Brasileira de Zootecnia, v. 23, n. 3, p. 396-403, 1996.

BOTREL, M.A.; EVANGELISTA, A.R.; VIANA, MC.M.; ALVIM, M.J.; PEREIRA, A.V.; LÉDO, F.J.D.S.; XAVIER, D.F. Avaliação de cultivares de alfafa em diferentes regiões do estado de Minas Gerais (compact disc). In: REUNIÃO DA SOCIEDADE BRASILEIRA DE ZOOTECNIA, 39., Recife, 2002. Anais. Recife: SBZ, 2002.

BOUTON, J. H. Desenvolvimento de cultivares tolerantes ao pastejo e à acidez do solo. In: SIMPOSIO SOBRE MANEJO DE PASTAGEM, 16. Piracicaba, 1999. Anais. Piracicaba: FEALQ, 1999, p. 47-67.

BOUTON, J.H.; SMITH, S.R.Jr.; WOOD, D.T.; HOVELAND, C.S.; BRUMMER, E.C. Registration of 'Alfagraze' alfalfa. Crop Science, v. 31, p. 479, 1991.

BRASIL. Ministério da Agricultura. Serviço Nacional de Pesquisa Agronômica. Comissão de Solos. Levantamento de reconhecimento dos solos do Estado de São Paulo. Rio de Janeiro, 1960. 634p. (Boletim, 12).

BRASIL. Ministério da Agricultura, do Abastecimento e da Reforma Agrária. Agricultura brasileira: desempenho em 1993. Brasília, 1994. p. 20-31: Pecuária. 
BRODERICK, G.A. Desirable characteristics of forage legumes for improving protein utilization in ruminants. Journal of Animal Science, v. 73, p. 2760-2773, 1995.

BRUMMER, E.C.; BOUTON, J.H. Plant traits associated with grazing-tolerant alfalfa. Agronomy Journal, v. 83, p. 996-1000, 1991.

BRUMMER, E.C.; BOUTON, J.H. Physiological traits associated with grazing-tolerant alfalfa. Agronomy Journal, v. 84, p. 138-143, 1992.

BRUMMER. E.C.; MOORE, K.J. Persistence of perennial cool-season grass and legume cultivars under continuous grazing by beef cattle. Agronomy Journal, v. 92, p. $466-471,2000$.

BURKART, A. Las leguminosas argentinas, silvestres y cultivadas. Buenos Aires: ACME Agency, 1952. 569p.

BUSCAGLIA, H.J.; VAN ES, H.M.; GEOHRING, L.D.; VERMEULEN H.C.A.M.; FICK, G.W.; LUCEY, R.F. Alfalfa yield and quality are affected by soil hydrologic conditions. Agronomy Journal, v. 86, p. 535-542, 1994.

BUXTON, D.R.; BRACHE, M.R. Digestibility of structural carbohydrates in coolseason grass and legume forages. Crop Science, v. 31, p. 1338-1345, 1991.

BUXTON, D.R.; FALES, S.L Plant environment and quality. In: FAHEY Jr.G.C. (Ed). Forage quality, evaluation, and utilization. Madison: American Society of Agronomy; Crop Science Society of America; Soil Science Society of America., 1994. p. 155-199. 
BUXTON, D.R.; HORNSTEIN, J.S. Cell-wall concentration and components in stratified canopies of alfalfa, birdsfoot trefoil, and red cover. Crop Science, v. 26, p. $180-184,1986$

BUXTON, D.R.; HORNSTEIN, J.S.; MARTEN, G.C. Genetic variation for forage quality of alfalfa stems. Canadian Journal of Plant Science, v. 67, p. 1057-1067, 1987.

CHACON, E.A.; STOBBS, T.H. Influence of progressive defoliation of a grass sward in the eating behaviour of cattle. Australian Journal of Agricultural Research, v. 27, p. 709-727, 1976.

CHACON, E.A.; STOBBS, T.H.; DALE, M.B. Influence of sward characteristics on grazing behaviour and growth of Hereford steers grazing tropical grass pasture. Australian Journal of Agricultural Research, v. 29, p. 89-102, 1978.

CHERMEY, D.J.R.; MERTENS, D.R.; MOORE, J.E. Intake and digestibility by wethers as influenced by forage morphology at three levels of forage offering. Journal of Animal Science, v. 68, p. 4387-4399, 1990.

CHRISTIAN, K.R. Effects of the environment on the growth of alfalfa. Advances in Agronomy, v. 29, p. 183-227, 1977.

COLLINS, M.; TAYLOR, T.H. Yield and quality of alfalfa harvested during autumn and winter and harvest effects on the spring crop. Agronomy Journal, v. 72, p. 839-844, 1980.

CORSI, M.; MARTHA JR, G.B.; GONÇALVES, J.R.S.; LIMA, L.G. Desempenho animal em pastagens de alfafa. In: SIMPOSIO SOBRE MANEJO DE PASTAGEM, 16. Piracicaba, 1999. Anais. Piracicaba: FEALQ, 1999, p. 133-153. 
COULMAN, B.; GOPLEN, B.; MAJAK, W.; McALLISTER, T.; CHENG, K.J.; BERG, B.; HALL, J.; McCARTNEY, D; ACHARYA, S. A review of the development of a bloat-reduced alfalfa cultivar. Canadian Journal of Plant Science, v. 80, p. 487491, 2000.

COUNCE, P.A.; BOUTON, J.H.; BROWN, R.H. Screening and characterizing alfalfa for persistence under mowing and continuous grazing. Crop Science, v. 24, p. 282$285,1984$.

DA SILVA, D. S.; QUEIROZ FILHO, J. L. D.; ARAÚJO, M. J. D.; BARROSO, D. D.; ANDRADE, M. V. M.; LIMA, P. J. S.; DA SILVA, M. A. Avaliação de 21 cultivares de alfafa (Medicago sativa L.) em Areia-PB (compact disc). In: REUNIÃO DA SOCIEDADE BRASILEIRA DE ZOOTECNIA, 39., Recife, 2002. Anais. Recife: SBZ, 2002.

DALL'AGNOL, M.; SCHEFFER-BASSO, S. M. Produção e utilização de alfafa. In: SIMPÓSIO SOBRE MANEJO DE PASTAGENS, 17., Piracicaba, 2000. Anais. Piracicaba: FEALQ, 2000. p. 265-295.

EMPRESA BRASILEIRA DE PESQUISA AGROPECUÁRIA. Sistema brasileiro de classificação de solos. Brasília, 1999. 412 p.

EUCLIDES, V.P.B. Alternativas para intensificação da produção de carne bovina em pastagens. Campo Grande: EMBRAPA Gado de corte, Empresa Brasileira de Pesquisa Agropecuária, 2000. 75 p.

FICK, G.W.; JANSON, C.G. Testing mean stage as a predictor of alfalfa forage quality with growth chamber trials. Crop Science, v. 30, p. 678-682, 1990. 
FICK, G.W.; ONSTAD, D.W. Statistical models for predicting alfalfa herbage quality from morphological or weather data. Journal of Production Agriculture, v. 1, p. 160-166, 1988.

FORBES, T.D.A.; COLEMAN, S.W. Forage intake and ingestive behavior of cattle grazing old world bluestems. Agronomy Journal, v. 85, p. 808-816, 1993.

GALLARDO, M.; GUAITA, M.S.; CASTILLO, A. Estrategias y resultados de modelos de lata produccion de leche en sistemas pastoriles. Santa Fé: INTA, Estación Experimental Agropecuária Rafaela, 1996, p. 101-112, (Publicación miscelánea, 81).

GRIFFIN, T.S.; CASSIDA, K.A.; HESTERMAN, O.B.; RUST, S.R. Alfalfa maturity and cultivar effects on chemical and in situ estimates of protein degradability. Crop Science, v. 34, p. 1654-1661, 1994.

HALL, M.H.; SMILES, W.S.; DICKERSON, R.A. Morphological development of alfalfa cultivars selected for higher quality. Agronomy Journal, v. 92, p. 1077$1080,2000$.

HAMMOND, A.C.; WILLIAMS, M.J.; OLSON, T.A.; GASBARRE, L.L.; LEIGHTON, E.A.; MENCHACA, M.A. Effects of rotational vs. Intensive continuous stocking of bahiagrass on performance of Angus cows and calves and interactions with sire influence on gastrointestinal nematode infestation. Journal of Animal Science, v. 75, p. 2291-2299, 1997.

HARLAN, D.W.; HOLTER, J.B.; HAYES, H.H Detergent fiber traits to predict productive energy of forages fed free choice to nonlactating dairy cattle. Journal of Dairy Science, v. 74, p. 1337-1353, 1990. 
HERLING, V.R.; LUZ, P.H.C.; GOMIDE, C.A.; ZANETTI, M.A.; LIMA, C.G.; CORRADINI JUNIOR, R. Efeitos de época do primeiro corte sobre algumas características agronômicas da alfafa crioula (Medicago sativa L. cv. crioula). In: REUNIÃO DA SOCIEDADE BRASILEIRA DE ZOOTECNIA, 35., Botucatu, 1998. Anais. Botucatu: SBZ, 1998. p. 527-529.

HINTZ, R.W.; ALBRECHT, K.A. Prediction of alfalfa chemical composition from maturity and plant morphology. Crop Science, v. 31, p. 1561-1565, 1991

HODGSON, J. Grazing management: science into practice. London: Longman Scientific and Technical, 1990. 203p.

HRISTOV, A.N.; HUHTANEN, P.; RODE, L.M.; ACHARYA, S.N.; McALlISTER, T.A. Comparison of the ruminal metabolism of nitrogen form ${ }^{15} \mathrm{~N}$-labeled alfalfa preserved as hay or as silage. Journal of Dairy Science, v. 84, p. 2738-2750, 2001.

INSTITUTO BRASILEIRO DE GEOGRAFIA E ESTATÍSTICA Anuário Estatístico do Brasil: 1993. v. 53.

INSTITUTO BRASILEIRO DE GEOGRAFIA E ESTATÍSTICA Anuário Estatístico do Brasil: 2002. http://www.ibge.gov.br. (10 mar. 2003).

IWAASA, A.D.; BEAUCHEMIN, K.A.; BUCHANAN-SMITH, J.G.; ACHARYA, S.N. Effects of stage of maturity and growth cycle on shearing force and cell wall chemical constituents of alfalfa stems. Canadian Journal of Animal Science, v. 76, p. 321-328, 1996.

JUNG, G.A.; SHAFFER, J.A.; EVERHART, J.R. Harvest frequency and cultivar influence on yield and protein of alfalfa-ryegrass mixtures. Agronomy Journal, v. 88, p. 817-822, 1996. 
JUNG, H.G.; ENGELS, F.M. Alfalfa stem tissues: cell wall deposition, composition, and degradability. Crop Science, v. 42, p. 524-534, 2002.

KALLENBACH, R.L.; NELSON, C.J.; COUTTS, J.H. Yield, quality, and persistence of grazing- and hay-type alfalfa under three harvest frequencies. Agronomy Journal, v. 94, p. 1094-1103, 2002.

KALU, B.A.; FICK, G.W. Quantifying morphological development of alfalfa for studies of herbage quality. Crop Science, v. 21, p. 267-271, 1981.

KALU, B.A.; FICK, G.W. Morphological stage of development as a predictor of alfalfa herbage quality. Crop Science, v. 23, p. 1167-1172, 1983.

KARNEZOS, T.P.; MATCHES, A.G.; BROWN, C.P. Spring lamb production on alfalfa, sainfoin, and wheatgrass pastures. Agronomy Journal, v. 86, p. 497-502, 1994.

KRAMER, J. H. Produção de leite em sistemas confinados: mais leite significa mais dinheiro. In: SIMPÓSIO SOBRE PRODUÇÀO DE LEITE NO BRASIL, 1., Viçosa, 1999. Desafios tecnológicos para produção de leite no Brasil: Anais. Viçosa, UFV, 1999, p. 21-28.

LAMB, J.B; ADAMS, D.C.; KLOPFENSTEIN, T.J.; GRANT, R.J.; SIMS, P.L.;WHITE, L.M.; WALLER, S.S. Intake and digestive kinetics of leaf and stem fraction. Journal of Range Management, v. 55, p. 57-64, 2002.

LANYON, L. E.; GRIFFITH, W. K. Nutrition and fertilizer use. In: HANSON, D. K.; BARNES, D.K.; HILL JUNIOR, R. R. (Ed.). Alfalfa and alfalfa improvement. Madison: American Society of Agronomy, 1988. p. 333-372. 
LEMAIRE, G.; CHAPMAN, D. Tissue flows in grazed plant comunities. In: HODGSON, J.; ILLIUS, E. (Ed.). The ecology and management of grazing systems. London: CAB International, 1996. cap. 1, p. 3-36.

LITTELL, R. C.; MILLIKEN, G. A.; STROUP, W. W.; WOLFINGER, R. D. SAS ${ }^{\circledR}$ system for mixed models. Cary: SAS Institute, 1996. 633p.

LLOVERAS, J.; FERRAN, J; ALVAREZ, A.; TORRES, L. Harvest management effects on alfalfa (Medicago sativa L.) production and quality in Mediterranean areas. Grass and Forage Science, v. 53, p. 88-92, 1998.

LOSADA, M.R.M.; RODRÍGUEZ, A.G.; RODRIGUEZ, A.R. Sward quality affected by different grazing pressures on dairy systems. Journal of Range Management, v. 53 , p. $603-610,2000$.

MAJAK, W.; HOWARTH, R.E.; FESSER, A.C.; GOPLEN, B.P.; PEDERSON, M.W. Relationships between ruminal bloat and composition of alfalfa herbage. II. Saponins. Canadina Journal of Animal Science, v. 60, p. 699-708, 1980.

MARTEN, G.C.; BUXTON, D.R.; BARNES, R.F. Feeding Value (Forage Quality). In: HANSON, D K.; BARNES, D.K.; HILL JUNIOR, R. R. (Ed.). Alfalfa and alfalfa improvement. Madison: American Society of Agronomy, 1988. p. 463-491.

McMAHON, L.R.; McALLISTER, T.A.; BERG, B.P.; MAJAK, W.; ACHARYA, S.N.; POPP, J.D.; COULMAN, B.E.; WANG, Y.; CHENG, K.J. A review of the effects of forage condensed tannins on ruminal fermentation and bloat in grazing cattle. Canadian Journal of Plant Science, v. 80, p. 469-485, 2000. 
MICHAUD, R.; LEHMAN, W.F.; RUMBAUGH, M.D. World distribution and historical development. In: HANSON, D. K.; BARNES, D.K.; HILL JUNIOR, R. R. (Ed.). Alfalfa and alfalfa improvement. Madison: American Society of Agronomy, 1988. p. 25-91.

MONTEIRO, A.L G. Estudos morfológicos e fisiológicos da rebrota de cultivares não dormentes de alfafa (CUF-101 e Crioula) a partir do manejo de área foliar de perfilhos basilares. Piracicaba, 1989. 139p. Dissertação (Mestrado) - Escola Superior de Agricultura “Luiz de Queiroz”, Universidade de São Paulo.

MONTEIRO, A.L.G.; COSTA, C.; SILVEIRA, A.C. Produção e distribuição de matéria seca e composição bromatológica de cultivares de alfafa (Medicago sativa L.). Revista Brasileira de Zootecnia, v. 27, n. 5, p. 868-874, 1998.

MOORE, K.C.; NELSON, C.J. Economics of forage production and utilization. In: Forages an introduction to grassland agriculture.5. ed. Ames: Iowa State University Press, 1995. v. 1, p. 189-202.

NELSON, C.J.; MOSER, L.E. Plant factor affecting forage quality. In: FAHEY Jr. G.C. (Ed.). Forage quality, evaluation, and utilization. Madison: American Society of Agronomy; Crop Science Society of America; Soil Science Society of America, 1994. p.115-154.

NORDKIVIST, E.; ÅMAN, P. Changes during growth in anatomical and chemical composition and in-vitro degradability of lucerne. Journal of the Science of Food and Agriculture, v. 37, p. 1-7, 1986.

NATIONAL RESEARCH COUNCIL. Nutrients requirements of dairy cattle. 7. ed. Washington: National Academic Press, 2001. 381p. 
NUERNBERG, N.J.; MILAN, P.A ; SILVEIRA, C.A.M. Cultivo, manejo e utilização da alfafa. In: EMPRESA CATARINENSE DE PESQUISA AGROPECUARIA. Manual de produção de alfafa. Florianópolis, 1990. p. 15-61.

NUSSIO, L.G.; MANZANO, R.P. Valor nutritivo e conservação. In: SIMPÓSIO SOBRE MANEJO DE PASTAGENS, 16., Piracicaba, 1999. Anais. Piracicaba: FEALQ, 1999. p. 153-173.

OLIVEIRA, P.R.D. Avaliação da produção e da qualidade de cultivares de alfafa (Medicago sativa L.). Piracicaba, 1986. 67p. Dissertação (Mestrado) - Escola Superior de Agricultura “Luiz de Queiroz”, Universidade de São Paulo.

OLIVEIRA, P.R.D.; PAIM, N.R.; CZERMAINSKI, A.B.C. Seleção para rendimento e qualidade da forragem em alfafa crioula. Pesquisa Agropecuária Brasileira, v. 28, n. 9, p. 1039-1044, 1993.

OLIVEIRA, W. S. Seleção de cultivares de alfafa (Medicago sativa L.) eficientes em produção e qualidade da biomassa. Piracicaba, 2001. 118p. Tese (Doutorado)Centro de Energía Nuclear na Agricultura, Universidade de São Paulo.

ONSTAD, D.W.; FICK, G.W. Predicting crude protein, in vitro true digestibility, and leaf proportion in alfalfa herbage. Crop Science, v. 23, p. 961-964, 1983.

PARKER, W.J.; MULLER, L.D.; BUCKMASTER, D.R. Management and economic implications of intensive grazing on dairy farms in the northeastern states. Journal of Dairy Science, v. 75, n. 9, p. 2587-2579, 1992.

PARSONS, A.J.; LEAFE, E.L.; COLLETT, B.; STILES, W. The physiology of grass production under grazing. I. Characteristics of leaf and canopy photosynthesis of continuously-grazed swards. Journal of Applied Ecology, v. 20, p. 117-126, 1983. 
PATERSON, J.A.; BELYEA, R.L.; BOWMAN, J.P.; KERLEY, M.S.; WILLIAMS, J.E. The impact of forage quality and supplementation regimen on ruminant animal intake and performance. In: FAHEY Jr. G.C. (Ed.). Forage quality, evaluation, and utilization. Madison: American Society of Agronomy; Crop Science Society of America; Soil Science Society of America, 1994. p.59-114.

PEDREIRA, C. G. S. Avanços metodológicos na avaliação de pastagens. In: REUNIÃO DA SOCIEDADE BRASILEIRA DE ZOOTECNIA, 39., Recife, 2002. Anais. Recife: SBZ, 2002. p. 100-150.

POPP, J.D.; McCAUGHEY, E.P.; COHEN, R.D.H. Grazing system and stocking rate effects on the productivity, botanical composition and soil surface characteristics of alfalfa-grass pastures. Canadian Journal of Animal Science, v. 77, p. 669-676, 1997.

POPP, J.D.; McCAUGHEY, E.P.; COHEN, R.D.H.; McALLISTER, T.A.; MAJAK, W. Enhancing pasture productivity with alfalfa: A review. Canadian Journal of Plant Science, v. 80, p. 513-519, 2000.

ROBERTSON, J.B.; VAN SOEST, R.L. The detergent system of analysis and its application to humans foods. In: JAMES, W.P.T; THEANDER, O. (Ed.). Alasysis of dietary fiber in food. New York: Marcel Dekker, 1981. v. 3, 123 p.

ROBISON, G.D.; MASSENGALE, M.A. Effect of harvest management and temperature on forage yield, root carbohydrates, plant density and leaf area relationships in alfalfa (Medicago sativa L. cultivar 'Moapa'). Crop Science, v. 8, p. $147-151,1968$. 
ROSTON, D.M. Manejo e disposição de resíduos gerados pela bovinocultura leiteira. In: MATTOS, W.R.S. (Ed.). A produção animal na visão dos brasileiros. Piracicaba: FEALQ; SBZ, 2001. p. 395-422.

RUGGIERI, A.C.; ALMEIDA, A.R.P.; FIGUEIREDO, L.A.; BOTREL, M.A. Comportamento de 20 cultivares de alfafa com 3 anos de cultivo em Sertaõzinho-SP (compact disc). In: REUNIÃO DA SOCIEDADE BRASILEIRA DE ZOOTECNIA, 39., Recife, 2002. Anais. Recife: SBZ, 2002.

SANDERSON, M.A. Predictors of alfalfa forage quality: validation with field data. Crop Science, v. 32, p. 245-250, 1992.

SANTOS, J.E.P.; SANTOS, F.A.P. Automação em sistemas de produção de leite. In: MATTOS, W.R.S. (Ed.). A produção animal na visão dos brasileiros. Piracicaba: FEALQ; SBZ, 2001. p. 375-382.

SAS INSTITUTE. SAS user's guide: release 6.03 ed. Cary, 1988. 1028p.

SHAVER, R.D.; NYTES, AJ.; SATTER, L.D.; JORGENSEN, N.A. Influence of feed intake, forage physical form, and forage fiber content on particle size of masticated forage, ruminal digesta, and feces of dairy cows. Journal of Dairy Science, v. 71, p. 1566-1572, 1988.

SHEAFFER, C.C.; CASH, D.; EHLKE, N.J.; HENNING, J.C.; JEWETT, J.G.; JOHNSON, K.D.; PETERSON, M.A.; SMITH, M.; HANSEN, J.L.; VIANDS, D.R. Entry $\times$ environment interactions for alfalfa forage quality. Agronomy Journal, v. 90, p. 774-780, 1998. 
SHEAFFER, C.C.; MARTIN, N.P.; LAMB, J.F.S.; CUOMO, G.R.; JEWETT, J.G.; QUERING, S.R. Leaf and stem properties of alfalfa entries. Agronomy Journal, v. 92, p. 733-739, 2000.

SINGH, Y.; WINCH, J.E. Morphological development of two alfalfa cultivars under various harvesting schedules. Canadian Journal of Plant Science, v. 54, p. 79-87, 1974.

SLEUGH, B.; MOORE, K.J.; GEOREGE, J.R.; BRUMMER, E.C. Binary legume-grass mixtures improve forage yield, quality, and seasonal distribution. Agronomy Journal, v. 92, p. 24-29, 2000.

SMALL, E.; JOMPHE, M. A synopsis of the genus Medicago (Leguminosae). Canadian Journal of Botany, v. 67, p. 3260-3294, 1989.

SMART, A.J.; SCHACHT, W.H.; MOSER, L.E. Predicting leaf/stem ratio and nutritive value in grazed and nongrazed Big Bluestem. Agronomy Journal, v. 93, p. 12431249, 2001.

SMITH, D. Influence of temperature on the yield and chemical composition of five forage legume species. Agronomy Journal, v. 62, p. 520-523, 1970a.

SMITH, D. Yield and chemical composition of leaves and stems of alfalfa at intervals up the shoots. Journal of Agriculture and Food Chemistry, v. 18, n. 4, p.652-656, 1970b.

SMITH Jr., S.R.; BOUTON, J.H. Selection within alfalfa cultivars for persistence under continuous stocking. Crop Science, v. 33, p. 1321-1328, 1993. 
SMITH Jr., S.R.; BUTTON, J.H.; HOVELAND, C.S. Alfafa persistence and regrowth potential under continuous grazing. Agronomy Journal, v. 81, p. 960-965, 1989.

SMITH Jr., S.R.; BUTTON, J.H.; HOVELAND, C.S. Persistence of alfalfa under contiuous grazing in pure stands and in mixtures with tall fescue. Crop Science, v. 32, p. 1259-1264, 1992.

SMITH Jr., S.R.; BOUTON, J.H.; SINGH, A.; McCAUGHEY, W.P. Development and evaluation of grazing-tolerant alfalfa cultivars: A review. Canadian Journal of Plant Science, v. 80, p. 503-512, 2000.

SOIL SURVEY STAFF. Keys to soil taxonomy. 4. ed. Blacksburg: Virginia Polytechnic Institute State University Press, 1990. 422p. (Soil Management Support Services Technical Monograph, 19)

SULC, R.M.; ALBERCHT, K.A.; CHERNEY, J.H.; HALL, M.H.; MUELLER, S.C.; ORLOFF, S.B. Field testing a rapid method for estimating quality. Agronomy Journal, v. 89, p. 952-957, 1997.

TILLEY, J.M.A.; TERRY, R.A. A two-stage technique for the in vitro digestion of forage crops. Journal of the British Grassland Society, v. 18, p. 104-111, 1963.

TREMBLAY, G.F.; MICHAUD, R.; BÉlANGER, G.; McRAE, K.B; PETIT, H.V. In vitro ruminal undegradable proteins of alfalfa cultivars. Canadian Journal of Plant Science, v. 80, p. 315-325, 2000.

TURNBULL, G.W.; CLAYPOOL, D.W.; DUDLEY, E.G. Performance of lactating cows fed alfalfa hays graded by relative feed value system. Journal of Dairy Science, v. 65, p. 1205-1211, 1982. 
VAN KEUREN, R.W.; MATCHES, A.G. Pastures production and utilization. In: HANSON, D. K.; BARNES, D.K.; HILL, R.R. JUNIOR (Ed.). Alfalfa and alfalfa improvement. Madison: American Society of Agronomy, 1988. p. 515-532.

VAN SOEST, P.J. Nutritional ecology of the ruminant. Corvallis: O \& B Books, 1982. $373 \mathrm{p}$.

VAN SOEST, P.J.; ROBERTSON, J.B.; LEWIS, B.A. Methods for dietary fiber, neutral detergent fiber, and nonstarch, polysaccharides in relation to animal nutrition. Journal of Dairy Science, v.74, p. 3583-3597, 1991.

VAUGHN, D.L.; VIANDS, D.R.; LOWE, C.C. Nutritive value and forage yield of alfalfa synthetics under three harvest management systems. Crop Science, v. 30, p. 699-703, 1990.

VIANA, M.C.M.; KONZEN, E.A.; PURCINO, H.M.A. Comportamento de 28 cultivares de alfafa nas condições de cerrado de Sete Lagoas, MG. In: REUNIÃO DA SOCIEDADE BRASILEIRA DE ZOOTECNIA, 35., Botucatu, 1998. Anais. Botucatur SBZ, 1998. p. 620-622.

VILELA, D. Potencialidade do pasto de alfafa (Medicago sativa L.) para produção de leite. In: WORSHOP SOBRE POTENCIAL FORRAGEIRO DA ALFAFA (Medicago sativa L.) NOS TRÓPICOS, Juiz de Fora, 1994. Anais. Juiz de Fora: EMBRAPA,CNPGL, 1994. p. 205-217.

VOUGH, L.R.; MARTEN, G.C. Influence of soil moisture and ambient temperature on yield and quality of alfalfa forage. Agronomy Journal, v. 63, p. 40-42, 1971. 
WILLIAMS, M.J.; HAMMOND, A.C. Rotational vs. continuous intensive stocking management of bahiagrass pasture for cows and calves. Agronomy Journal, v. 91, p. 11-16, 1999.

WILSON, J.R. Structural and anatomical, traits of forages influencing their nutritive value for ruminants. In: GOMIDE, J.A. (Ed.). INTERNATIONAL SYMPOSIUM ON ANIMAL PRODUCTION UNDER GRAZING, Viçosa, 1997. Anais. Viçosa: SBZ, 1997. p. 173-208.

YANG, C.M.J. Response of forage fiber degradation by ruminal microorganisms to branched-chain volatile fatty acids, amino acids, and dipeptides. Journal of Dairy Science, v. 85, p. 1183-1190, 2002.

YANG, W.Z; BEAUCHEMIN, K.A.; RODE, L.M. Effects of particle size of alfalfabased dairy cow diets on site and extent of digestion. Journal of Dairy Science, v. 85, p. 1958-1968, 2002.

ZIMMER, A. H.; EUCLIDES FILHO, K. Brazilian pasture and beef production. In: GOMIDE, J.A. (Ed.). INTERNATIONAL SYMPOSIUM ON ANIMAL PRODUCTION UNDER GRAZING, Viçosa, 1997. Anais. Viçosa: SBZ, 1997. p. $1-29$.

ZIMMER, A.; SILVA, M. P.; MAURO, R. Sustentabilidade e impactos ambientais da produção animal em pastagens. In: SIMPÓSIO SOBRE MANEJO DE PASTAGENS, 19., Piracicaba, 2002. Anais. Piracicaba: FEALQ, 2002. p. 31-58. 